\title{
DOMESTIC POLICIES, NATIONAL SOVEREIGNTY AND INTERNATIONAL ECONOMIC INSTITUTIONS
}

\author{
Kyle Bagwell \\ Robert W. Staiger \\ Working Paper 7293 \\ http://www.nber.org/papers/w7293
NATIONAL BUREAU OF ECONOMIC RESEARCH
1050 Massachusetts Avenue
Cambridge, MA 02138
August 1999

\begin{abstract}
We thank seminar participants at Wisconsin and the New York Federal Reserve Bank for helpful comments on an early version of this paper. The views expressed herein are those of the authors and not necessarily those of the National Bureau of Economic Research.

(C) 1999 by Kyle Bagwell and Robert W. Staiger. All rights reserved. Short sections of text, not to exceed two paragraphs, may be quoted without explicit permission provided that full credit, including $\mathbb{C}$ notice, is given to the source.
\end{abstract}


Domestic Policies, National Sovereignty

and International Economic Institutions

Kyle Bagwell and Robert W. Staiger

NBER Working Paper No. 7293

August 1999

JEL No. F02, F13, F15

\section{ABSTRACT}

To what extent must nations cede control over their economic and social policies if global efficiency is to be achieved in an interdependent world? This question is at the center of the debate over the future role of GATT (and its successor, the WTO) in the realm of labor and environmental standards. Current GATT rules reflect the primacy of market access concerns in GATT practice, and this orientation is seen increasingly as unfriendly to labor and environmental causes. Fundamental changes to GATT are being considered as a result, changes that would expand the scope of GATT negotiations to include labor and environmental policies, and would lead to a significant loss of sovereignty for national governments. In this paper we establish that there is no need for the WTO to expand the scope of its negotiations in this way. We show instead that the market access focus of current GATT rules is well-equipped to handle the problems associated with choices over labor and environmental standards, and that with relatively modest changes that grant governments more sovereignty, not less, these rules can in principle deliver globally efficient outcomes.

Kyle Bagwell

Department of Economics

Columbia University

420 West 188th Street, IAB

New York, NY 10027

and NBER

kw8@columbia.edu
Robert W. Staiger

Department of Economics

The University of Wisconsin

1180 Observatory Drive

Madison, WI 53705

and NBER

rstaiger@facstaff.wisc.edu 


\section{Introduction}

To what extent must nations cede control over their economic and social policies if global efficiency is to be achieved in an interdependent world? This question is at the center of the debate over the appropriate scope of international economic institutions such as the GATT (and now its successor, the WTO), where member-countries are considering proposals that would broaden GATT's orientation beyond conventional trade policy measures to include negotiations over labor and environmental standards. Such proposals appear to encroach on traditional limits of national sovereignty, and they raise fundamental questions about the structure of international economic relations among sovereign states. An important question therefore concerns the minimal range of policies over which international negotiations must proceed if global efficiency is to be achieved.

As currently structured, GATT's central focus is on the removal of trade barriers to market access, and its approach to labor and environmental standards is best characterized as somewhere between "neglect" and "benign neglect." There are really two dimensions of GATT's approach to these issues, and they correspond to (i) the freedom each country has to determine its own domestic standards (i.e., the range of domestic standards that are GATT-legal), and (ii) the freedom each country has to respond with trade measures to the (GATT-legal) standards chosen by its trading partners. To understand the implications of GATT rules along these two dimensions, it is helpful to distinguish further between domestic standards that relate to production (e.g., a country's child labor laws or its regulations regarding the disposal of industrial waste) and domestic standards that relate to consumption (e.g., a country's recycling laws or its regulations controlling the sale and distribution of the products of prison labor). In general, countries have broad freedom under GATT's rules to determine their own standards, though this freedom is somewhat greater with regard to production standards than it is with regard to consumption standards. On the other hand, as far as responding to the (GATT-legal) standards choices of their trading partners, countries face fairly significant limitations under GATT rules.

\footnotetext{
${ }^{1}$ See Dam (1970) and Jackson $(1969,1989)$ for authoritative accounts of GATT principles and practices. For a very useful discussion of the way standards are currently handled in the WTO, see Enders (1996).
} 
Consider first the case of production standards. The determination of such standards is regarded by GATT to be the legitimate domain of each national government. In effect, then, each country is free under GATT rules to determine its own labor and environmental standards as they relate to production processes within its borders, and in particular weak labor or environmental standards do not constitute a violation of GATT obligations. This is the first dimension of GATT's approach to production standards, and it has implications for the second dimension: the market access obligations (e.g., tariff bindings) that a GATT member does accept as a result of negotiation may not be later modified unilaterally in order to respond to the (weak) labor or environmental standards of a trading partner. ${ }^{2}$ Taken together, these two dimensions amount to "neglect," but GATT does not quite stop here, and it is this last element that introduces a "benign" aspect to the neglect of labor and environmental standards within GATT, at least in principle and as far as GATT's market access commitments are concerned. This last element concerns the general "right of redress" that a government has whenever it can show that market access commitments which it had previously negotiated are being systematically offset by an unanticipated change in the policies - any policies, but including labor and environmental standards - of another GATT member, even if these policy changes broke no explicit GATT rules. ${ }^{3}$ Under a successful "non-violation" complaint, the

\footnotetext{
${ }^{2}$ Hence, in the high-profile 1991 GATT tuna-dolphin dispute between the United States and Mexico, it was not the right of the United States to set its own environmental (production) standards with respect to the protection and conservation of dolphins that was challenged. What was challenged as GATT-illegal was the decision by the United States to impose a trade embargo against Mexican tuna imports in response to the environmental standards of Mexico. Note also that erecting trade restrictions per se in response to the labor or environmental standards of a trading partner is not GATT-illegal: if the tariff in question is not bound in a GATT schedule, then a country is of course free to raise the tariff for this (or any other) reason. And even where the tariff in question is covered by a GATT binding, the country could still raise the tariff through an Article XXVIII renegotiation, but what would distinguish this from a unilateral action is that the country would be obligated to make "compensatory adjustments" under which it lowered other tariffs or else face a "reciprocal" tariff increase from its trading partner.

${ }^{3}$ The right to bring these so-called "non-violation" complaints is provided in GATT Article XXIII, which also sets out procedures for "violation" complaints. Non-violation complaints have proven difficult to carry out in practice, and from 1947 through 1995 only 14 out of the more than 250 Article XXIII proceedings have centered on such complaints, and none of these explicitly involved labor or environmental standards (see, for example, Petersmann, 1997, pp. 135-176). Nevertheless, as Petersmann (1997, p. 172) explains, the function of non-violation complaints in GATT is to provide a check on the domestic policy autonomy of member-countries, "....and to prevent the circumvention of the provisions in GATT Article XXVIII...on 'Modification of Schedules' if a member, rather than withdrawing a concession de jure in exchange for compensation or equivalent withdrawals of concessions by affected contracting parties, withdraws a concession de facto." In this respect, the impact of the right to bring non-violation complaints may not be well-measured by the numbers of such complaints actually brought, and in principle this right
} 
complaining country is entitled to a "rebalancing" of market access commitments, wherein either its trading partner finds a way to offer compensation for the trade effects of its domestic policy change (typically in the form of other policy changes that restore the original market access) or the complaining country is permitted to withdraw an equivalent market access concession of its own. In principle, this last element therefore secures the balance of negotiated market access commitments against erosion as a result of future changes in labor or environmental standards.

Consider next the case of consumption standards. As with production standards, the determination of consumption standards is also considered by GATT to be the legitimate domain of each national government, but there is an important difference: whereas the implementation of production standards typically does not involve direct measures to restrict market access, consumption standards often require interference with or outright bans on imports that do not meet those standards, and this in turn will require a government to exercise special exemptions from its market access obligations. As such, the introduction of a stringent consumption standard offers governments a fairly direct route to reimpose, in a "disguised" form, protection they had previously negotiated away, and the freedom within GATT rules to set consumption standards is tempered for this reason. In effect, then, each country is free under GATT rules to determine its own labor and environmental standards as they relate to consumption within its borders, but unusually stringent consumption standards - and more specifically, the trade measures that are introduced to implement these standards - may constitute a violation of GATT obligations, if they are deemed to reflect protectionist motives. ${ }^{4}$ While GATT's rules concerning consumption standards are thus somewhat

may restrain governments in their decisions to alter labor and environmental standards just as with domestic policies more generally.

${ }^{4}$ More specifically, special exemptions from GATT Article I (non-discrimination), Article III (national treatment), Article XI (which prohibits the use of quantitative restrictions) and other articles are provided under GATT Article $\mathrm{XX}$, so that for example governments may restrict importation of the products of prison labor and impose trade restrictions as necessary to conserve exhaustible natural resources or to protect human, animal, or plant life or health. These exemptions appear to provide a broad loophole for the reimposition of "disguised" protection, but such use of Article XX is constrained by the specific circumstances under which it can be applied (recently elaborated in the WTO Agreement on Sanitary and Phytosanitary measures), and by the ability of trading partners to bring "violation" complaints under Article XXIII when they believe the Article XX exemption is being abused for protectionist purposes. A recent prominent example of an Article XX action that was successfully challenged under Article XXIII was the (violation) complaint brought by the United States and Canada against EC prohibitions on the importation of hormone- 
less permissive than with regard to production standards when it comes to the freedom countries have to set their own standards, the freedom to respond to the (GATT-legal) consumption standards of others is analogous to that for production standards: existing market access obligations can not be modified unilaterally, but a general right of redress exists if changes in the labor or environmental standards of a trading partner erode the balance of negotiated market access commitments.

In essence, then, current GATT rules reflect the primacy of market access concerns in GATT practice. As such, these rules are designed to provide governments with a legal framework within which to make and secure market access commitments, and subject to this they respect the sovereignty of domestic decisions over labor and environmental standards, as they allow each member government to choose its own domestic standards without GATT involvement so long as the existing market access commitments it has made are not undermined by those choices.

It is the wisdom of preserving this degree of national sovereignty over domestic labor and environmental policies, while at the same time negotiating successive multilateral agreements to liberalize world trade, that is now being challenged from various quarters in the United States and elsewhere in the industrialized world. In particular, the market access orientation of GATT's rules is increasingly seen as unfriendly to labor and environmental causes. A primary concern voiced by labor interests and social activists is that working conditions and wages in industrialized countries will suffer from trade liberalization as a result of increased import competition from countries where labor standards are weak or not enforced. Similar concerns are echoed by those who see trade as a threat to the environment. It is feared that trade pressures will delay the introduction or enforcement of stricter standards, and could even fuel a "race to the bottom," in which the labor and environmental standards of the industrialized world are compromised in the name of international "competitiveness." This fear is perhaps reinforced by GATT's apparent bias: countries do not violate GATT rules by pursuing weak labor and environmental standards, and they might violate GATT rules if they pursue labor or environmental (consumption) standards that are "too stringent."

treated beef. In this case, the EC (consumption and production) standard was set above internationally recognized standards, and was deemed to lack a sufficient scientific basis to justify the unusual stringency. 
These concerns are mounting, and fundamental changes to GATT are being considered as a result, changes that could lead to a significant loss of sovereignty for national governments. There are now proposals to introduce the issue of labor standards directly onto the negotiating agenda of the WTO, with the purpose of creating a "social clause" for the WTO. The proposed social clause would specify a set of minimum international labor standards, and then permit restrictions to be placed against imports from countries not complying with these minimum standards. With regard to environmental policies, the WTO has already taken concrete steps to explore ways to enhance the provisions of GATT dealing with trade and environment: as a result of the Uruguay Round, a WTO Committee on Trade and Environment was established for the purpose of identifying the relationships between trade and environmental measures and to make recommendations on whether any modifications to the provisions of the multilateral trading system are required. With the WTO already broadening its traditional scope to study ways to incorporate previously ignored aspects of national environmental policies and facing proposals for fundamental changes in its approach to the issue of domestic labor standards, it is a good time to consider the question: How should the issue of domestic standards be handled in the GATT/WTO?

We are, of course, not the first to ask this question (see, for example, the influential volumes edited by Bhagwati and Hudec, 1996). However, formal analytical results are scarce, and of those even fewer are concerned directly with the interaction between negotiated reductions in trade barriers and the choice of domestic standards. ${ }^{5}$ Yet it is within the context of sustained negotiations to liberalize world trade that the need to negotiate international agreements over labor and environmental standards has been most forcefully raised, and it is from the backdrop of GATT's successes in securing low levels of negotiated tariffs on a multilateral basis that the case for adding such standards to the negotiating agenda of the WTO must be evaluated. Hence, an understanding of the interaction between tariff negotiations and the determination of domestic standards seems a necessary starting point for assessing the claim that these standards will suffer as a result of trade

\footnotetext{
${ }^{5}$ For example, Brown, Deardorff and Stern (1996) focus on the welfare and terms-of-trade effects of the imposition of labor standards in the presence of free trade but do not consider the choice of tariff policy, while Srinivasan (1996) considers whether diversity of labor standards alters the case for free trade but is not concerned with whether trade liberalization might alter a country's choice of labor standards.
} 
liberalization, and therefore necessary as well for considering how the issue of labor and environmental standards ought to be approached by the WTO. In this regard, there is a small but growing formal literature on the question of "issue linkage" in trade agreements (see, for example, Ederington, 1999, and Spagnolo, 1999) in which this interaction is a central concern. These papers consider how to structure enforcement provisions when there is a range of policies over which governments are attempting to cooperate. In contrast, in this paper we abstract from issues of enforcement, and consider instead the complementary issue of how to structure negotiations when the scope of policies over which governments could negotiate is potentially broad. ${ }^{6}$

We explore this issue within a general equilibrium framework in which two countries trade two goods and governments make decisions over their trade policies (e.g., tariffs) and their domestic standards (e.g., labor and environmental policies) in pursuit of their own national objectives. In modeling government decisions, we follow our earlier work (Bagwell and Staiger, 1996, 1999a and 1999b) representing the objectives of each government as a general function of its local prices and terms of trade, and extend this approach in order to incorporate the presence of local standards. The advantages of this approach are twofold. First, it is very general, being consistent both with the traditional view that governments maximize national income by their policy choices and with the view embodied in leading political-economy models that governments are concerned about the distributional impacts of their policy choices as well. Second, by representing government objectives in this way, the channel through which one government's policy choices affect another government's welfare is made transparent. This helps to clarify both the potential problems that arise when governments focus their negotiations on tariffs alone and the manner in which various rules of negotiation may address these problems.

In understanding the potential problems associated with the choice of local standards and identifying potential solutions, a key question is whether governments are concerned directly with the standards choices of their trading partners or only indirectly to the extent that these choices have

\footnotetext{
${ }^{6}$ Adopting the specific focus of labor standards and following a partial equilibrium approach, Bagwell and Staiger (1998) also explore some of the general themes considered here.
} 
important trade effects. The former would be the case, for example, if environmental standards affected the extent of cross-border pollution (a non-pecuniary international externality). ${ }^{7}$ If there were no cross-border pollution flows, then governments might still care about the environmental standards adopted by their trading partners, as a result of the competitive effects that these standards choices could imply (a pecuniary international externality). Indeed, such competitive effects might fuel a race to the bottom, and in this case it is the indirect (trade) consequences of the standards choices of one country that concerns its trading partners.

It is clear that where serious non-pecuniary externalities are present (e.g., global warming), direct international negotiations to address these externalities are warranted. But it is also true that in this case the need to involve the WTO is dubious, except perhaps for reasons of enforcement (and even here the case is not without qualification; see, for example, Roessler, 1998, Ederington, 1999 and Spagnolo, 1999). The more pressing question for the WTO is whether and how to handle the pecuniary externalities associated with the choice of local standards, since these externalities travel through trade and are therefore inextricably intertwined with the business of the WTO. Be this as it may, our main finding established below is that there is no need for the WTO to expand the scope of its direct negotiations to include local standards such as labor and environmental policies. We show instead that the market access focus of current GATT rules is well-equipped to handle the pecuniary externalities associated with choices over labor and environmental standards, and that with relatively modest changes that grant governments more sovereignty, not less, GATT's rules can in principle protect governments from the inefficiencies generated by these externalities.

These results are established formally below, but the intuition for them can be readily described. In the absence of any form of international agreement, governments will tend to use their trade policies to restrict trade volumes to inefficiently low levels. This restricted market access is the fundamental inefficiency that a trade agreement such as GATT can correct. However, if an agreement is negotiated which covers only direct restrictions on trade such as tariffs, the unilateral

\footnotetext{
${ }^{7}$ The GATT tuna-dolphin dispute (see also note 2) may provide a good example in which a global commons problem was the core issue at stake, and the associated trade effects were secondary.
} 
urge to restrict market access will be deflected on to domestic policies such as labor and environmental standards, whose determination will then be distorted as a consequence of negotiated tariff liberalization. While introducing domestic standards directly onto the negotiating agenda could in principle allow governments to eliminate these new policy distortions, it is not necessary to do so: once the source of the unilateral incentive to distort domestic standards is understood to derive from a desire to undermine negotiated market access commitments, governments can maintain the right to unilaterally determine their own domestic standards without sacrificing global efficiency provided that they face appropriate restrictions on their choices which offset this incentive. These restrictions essentially require only that governments preserve the results of market access negotiations when setting their domestic standards.

Hence, governments can achieve efficient outcomes if they continue to use international negotiations as a forum within which to make market access commitments, and are then permitted to decide individually on the best national policy mix with which to deliver these commitments. This approach is in fact quite close to the logic of existing GATT principles as we have described this logic above. There is, however, one essential difference: whereas GATT's existing rules, and in particular the prospect of non-violation complaints, secure the balance of negotiated market access commitments against systematic erosion as a result of future changes in labor or environmental standards, these rules do not apply symmetrically when a government contemplates changes in domestic standards which would lead to greater market access for its trading partners. Our results therefore imply that, while GATT's existing rules may fail to deliver efficient outcomes in light of the labor and environmental policy choices available to governments, an alternative to direct negotiations over labor and environmental standards is to modify current GATT rules so as to permit governments to raise their bound tariffs to offset the competitive effects when making changes to labor or environmental policies that would increase access to their markets. The first main message of the paper is that, with this modification, which amounts to granting governments more sovereignty over their policy choices, GATT's rules would deliver globally efficient outcomes.

We stress that there is a key difference between harnessing the logic of GATT's current 
principles to address the issue of labor and environmental standards and negotiating a social clause. Under the logic of GATT's current principles, it can be argued that, from the implicit link created by the prospect of non-violation complaints, an explicit link should be forged - and indeed that this link should be strengthened - between a government's labor and environmental policies and its own market access commitments. In contrast, under the logic of a GATT social clause, countries could face restricted access to the markets of their trading partners if they do not meet a set of minimum standards, and so an explicit link would be forged between a government's labor and environmental policies and the market access commitments of its trading partners. Our results provide no formal basis for such a linkage, and this can be viewed as the second main message of our paper: while current GATT practice may fall short of addressing legitimate problems associated with the choice of labor and environmental standards, the logic of a GATT social clause is fundamentally flawed.

More broadly, we interpret our findings as indicating that GATT's existing principles offer a compelling solution to a key challenge that is now before the multilateral trading system. This is not to say that these principles are necessarily well-reflected in current GATT practice. There may well be desirable ways to strengthen GATT practice to bring it more in line with GATT principles. But our results do offer formal support for the view that fundamental changes in GATT's approach are not required to handle the contentious issues of labor and environmental standards.

The rest of the paper proceeds as follows. The next section presents the basic model and derives non-cooperative and efficient policy choices within this setting. The non-cooperative policy choices are shown to be inefficient, and the source of the inefficiency is interpreted. Sections III and IV then consider the efficiency properties of various approaches to negotiation. In section III we establish that international negotiations over tariffs alone will lead to inefficient outcomes in the absence of any restraints on domestic policy choices, and we then formally model and evaluate the impact of the restraints that GATT's existing rules place on these choices. In section IV we consider how GATT rules could be modified to achieve efficient outcomes. Finally, section V concludes. 


\section{The Basic Model}

In this section we develop a simple model of international trade within which the essential inefficiencies associated with unilateral choices of trade and domestic policies may be understood. With the problems created by unilateral policy choices identified, we then use this model in the remainder of the paper to characterize bargaining outcomes under alternative negotiating structures.

\section{A. The Economic Environment}

We begin with a description of the economic environment in which trade takes place. We work within a two-sector, two-country perfectly-competitive general equilibrium trade model, modified to capture the issue of local standards in a straightforward way. In particular, in addition to its choice of tariff policy, we allow for the possibility that a government may wish to impose local standards of various kinds in its economy, possibly reflecting "social concerns," but possibly also in an effort to correct any of a number of economic distortions that might arise from externalities associated with the private production and consumption decisions of its citizens. The essential restriction we place on the underlying motives for standards-setting is that these motives reflect local issues, and not concerns of an inherently global nature. As we discussed in the Introduction, where important global (non-pecuniary) spillovers are present, direct negotiations are clearly warranted. Our formal analysis pertains to standards issues that become a concern to governments as a result of their trading relationships.

More specifically, we assume that there are two countries, home (no *) and foreign (*), who trade two goods, $\mathrm{x}$ and $\mathrm{y}$, taken to be normal goods in consumption and produced under perfect competition. Let $\mathrm{x}(\mathrm{y})$ be the natural import good of the home (foreign) country, and define $p \equiv p_{x} / p_{y}$ $\left(p^{*} \equiv p_{x}^{*} / p_{y}^{*}\right)$ to be the local relative price facing home (foreign) producers and consumers. Local relative prices may differ across the two countries as a result of the tariff policies of each government. With $\mathrm{t}\left(t^{*}\right)$ representing the home (foreign) ad valorem import tariff which we take to be nonprohibitive, and with $\tau \equiv(1+t)$ and $\tau^{*} \equiv\left(1+t^{*}\right)$, we have $p=\tau p^{w} \equiv p\left(\tau, p^{w}\right)$ and $p^{*}=p^{w} / \tau^{*} \equiv p^{*}\left(\tau^{*}, p^{w}\right)$, where $p^{w} \equiv p_{x}^{*} / p_{y}$ is the "world" (i.e., untaxed) relative price. The foreign (home-country) terms of trade are then measured by $p^{w}\left(1 / p^{w}\right)$. We interpret $\tau>1 \quad(\tau<1)$ to be an import tax (import 
subsidy) and similarly for $\tau^{*} .8$

Production in each country will be determined by relative prices in the economy in light of the country's production possibilities set. However, a country's production possibilities set may itself be affected by the presence of a local production standard, which we represent by the parameter $s_{q}$ for the home country and $s_{q}^{*}$ for the foreign country. In principle, a local production standard could reflect any government policy that has an impact on the country's production possibilities frontier. For example, $s_{q}$ might represent the legal minimum (or maximum) working age in the home country, which might reflect social concerns but could affect the home country's production possibilities through its impact on home-country labor supply. Alternatively, $s_{q}$ might correspond to a minimum real wage, the maintenance of which might comprise a societal goal but could affect the home country's production possibilities under the implied factor-market distortion. ${ }^{9}$ Or $s_{q}$ might represent the maximum legal emissions level per unit of production in the home country, which might correct an economic distortion but could affect the home country's production possibilities through its impact on the technologies available to home-country producers. ${ }^{10}$

In any event, as we have ruled out the existence of international non-pecuniary externalities by assumption, the local production standards set by one country will have no direct (i.e., nonpecuniary) effect on the production (or consumption) decisions of its trading partner. With a

\footnotetext{
${ }^{8}$ The Lerner symmetry theorem ensures that trade taxes or subsidies can be equivalently depicted as applying to exports or to imports in this two-sector general equilibrium setting.

${ }^{9}$ See Brecher (1974) for a derivation of the production possibilities frontier and the determination of production in a minimum-wage economy trading in international markets. Similarly, Bhagwati and Srinivasan (1971) analyze the implications of sectoral wage differentials for an economy's production relationships.

${ }^{10}$ For instance, if more efficient technologies also produce greater emissions, then tight local emissions standards may effectively preclude the use of the most efficient technologies in a country. More generally, the allowable level of pollution emissions associated with production might also affect production possibilities directly, if for example emissions levels in one sector alter directly the productive efficiency of the other. To avoid added complications, we do, however, assume that any non-pecuniary production externalities of this sort are not so severe as to lead to nonconvexities in the production set. For notational simplicity, we also rule out the existence of non-pecuniary externalities between local consumption and production decisions, though these complications could be handled without changing the thrust of our analysis.
} 
country's local production standard affecting the shape of its production possibilities frontier, and with the local relative price determining where on the frontier competitive producers will locate in light of those standards, production in a country will be determined by both its local relative price and its local production standard level. Hence, production standards will "shift" the (general equilibrium) supply functions of each country, and we therefore represent home and foreign production levels, respectively, by the functions $Q_{i}=Q_{i}\left(s_{q}, p\right)$ and $Q_{i}{ }^{*}=Q_{i}{ }^{*}\left(s_{q}{ }^{*}, p^{*}\right)$ for $i \in\{x, y\} .^{11}$

Consumption, too, will be a function of both the local relative price and the local production standard level in a country - the former defining the tradeoff faced by consumers, and the former and the latter together determining the level and distribution of factor income in the economy - but consumption will also be influenced by the level of tariff revenue collected $\mathrm{R}\left(R^{*}\right)$, which is distributed lump-sum to home (foreign) consumers and which we measure in units of the local export good at local prices. Moreover, governments may impose a local consumption standard, which we represent by $s_{c}$ for the home country and $s_{c}{ }^{*}$ for the foreign country. In principle, such standards might place national restrictions on the consumption of products made in a particular way or possessing a particular attribute (e.g. a national ban on the consumption of hormone-treated beef).

Again, as we have ruled out the existence of international non-pecuniary externalities by assumption, the local consumption standards set by one country will have no direct (i.e., nonpecuniary) effect on the consumption (or production) decisions of its trading partner. In analogy with our representation of production standards, we therefore treat consumption standards as additional shift parameters in the (general equilibrium) consumption functions of each country, and represent home and foreign consumption as $D_{i}=D_{i}\left(s_{q}, s_{c}, p, R\right)$ and $D_{i}^{*}=D_{i}^{*}\left(s_{q}^{*}, s_{c}^{*}, p^{*}, R^{*}\right)$ respectively, for $i \in\{x, y\}$. Tariff revenue is then defined implicitly for the home country by $R=\left[D_{x}\left(s_{q}, s_{c}, p, R\right)-Q_{x}\left(s_{q}, p\right)\right]\left[p-p^{w}\right]$ or $R=R\left(s_{q}, s_{c}, p, p^{w}\right)$, and similarly for the foreign country tariff

\footnotetext{
${ }^{11}$ In assuming that $Q_{i}$ and $Q_{i}^{*}$ are functions, we are abstracting from the possibility of multiple equilibria, and are thus implicitly placing limits on the kind and degree of distortions that are allowed. We also abstract from the possibility that these functions may be non-differentiable. Similar observations apply to the consumption functions we define below. Our analysis can be extended in a natural way to handle these complications while preserving the flavor of the results presented below.
} 
revenue is given by $R^{*}=\left[D_{y}^{*}\left(s_{q}{ }^{*}, s_{c}{ }^{*}, p^{*}, R^{*}\right)-Q_{y}{ }^{*}\left(s_{q}{ }^{*}, p^{*}\right)\right]\left[1 / p^{*}-1 / p^{w}\right]$ or $R^{*}=R^{*}\left(s_{q}{ }^{*}, s_{c}{ }^{*}, p^{*}, p^{w}\right)$, with each country's tariff revenue an increasing function of its terms of trade under the assumption that goods are normal in consumption. Home and foreign national consumption levels are thus given by $C_{i}\left(s_{q}, s_{c}, p, p^{w}\right) \equiv D_{i}\left(s_{q}, s_{c}, p, R\left(s_{q}, s_{c}, p, p^{w}\right)\right)$ and $C_{i}^{*}\left(s_{q}{ }^{*}, s_{c}{ }^{*}, p^{*}, p^{w}\right) \equiv D_{i}^{*}\left(s_{q}^{*}, s_{c}{ }^{*}, p^{*}, R^{*}\left(s_{q}{ }^{*}, s_{c}{ }^{*}, p^{*}, p^{w}\right)\right)$ for $i \in\{x, y\}$, respectively.

To complete our characterization of the economic environment, we introduce notation for imports and exports, so that the trade balance and equilibrium conditions may be expressed. For the home country, imports of $\mathrm{x}$ are represented as $M_{x}\left(s_{q}, s_{c}, p, p^{w}\right) \equiv C_{x}\left(s_{q}, s_{c}, p, p^{w}\right)-Q_{x}\left(s_{q}, p\right)$, while $E_{y}\left(s_{q}, s_{c}, p, p^{w}\right) \equiv Q_{y}\left(s_{q}, p\right)-C_{y}\left(s_{q}, s_{c}, p, p^{w}\right)$ denotes home-country exports of y. Foreign country imports of $\mathrm{y}, M_{y}^{*}$, and exports of $\mathrm{x}, E_{x}^{*}$, are similarly defined. Home and foreign budget constraints imply that, for any world price, we have

$$
p^{w} M_{x}\left(s_{q}, s_{c}, p\left(\tau, p^{w}\right), p^{w}\right)=E_{y}\left(s_{q}, s_{c}, p\left(\tau, p^{w}\right), p^{w}\right)
$$

$$
M_{y}^{*}\left(s_{q}^{*}, s_{c}^{*}, p^{*}\left(\tau^{*}, p^{w}\right), p^{w}\right)=p^{w} E_{x}^{*}\left(s_{q}^{*}, s_{c}^{*}, p^{*}\left(\tau^{*}, p^{w}\right), p^{w}\right)
$$

where we now represent explicitly the functional forms of the local prices. Finally, the equilibrium world price $\tilde{p}^{w}\left(\tau, s_{q}, s_{c}, \tau^{*}, s_{q}^{*}, s_{c}^{*}\right)$ is determined by the X-market-clearing condition

$$
M_{x}\left(s_{q}, s_{c}, p\left(\tau, \tilde{p}^{w}\right), \tilde{p}^{w}\right)=E_{x}^{*}\left(s_{q}^{*}, s_{c}^{*}, p^{*}\left(\tau^{*}, \tilde{p}^{w}\right), \tilde{p}^{w}\right)
$$

with market clearing for good y then implied by (1) and (2).

In summary, given local standards in each country and a pair of tariffs, the equilibrium world price is implied by (2), and the equilibrium world price and the given tariffs then together determine the local prices. In this way, the local standards and tariffs imply local and world prices, and thereby the levels for production, consumption, imports, exports and tariff revenue. Finally, we assume that the standard Marshall-Lerner stability conditions are met, so that an inward shift of the domestic (foreign) import demand curve results in a lower (higher) equilibrium world price. We further add the restrictions that $d p / d \tau>0>d p^{*} / d \tau^{*}$ and $\partial \tilde{p}^{w} / \partial \tau<0<\partial \tilde{p}^{w} / \partial \tau^{*}$, which ensure that the equilibrium prices do not exhibit the Lerner or Metzler paradoxes. 


\section{B. Government Objectives}

We next offer a general representation of government preferences. While it is customary to represent a government's payoff (i.e., welfare) directly in terms of the underlying choice variables (i.e., tariffs and local standards), we choose to represent government objectives in a somewhat different manner, extending the approach taken in Bagwell and Staiger (1996, 1999a, 1999b) in order to incorporate the presence of local standards. To this end, we represent government preferences over tariffs as preferences instead over the local and world prices that the tariff choices imply for given local standard levels; similarly, we separate government preferences over local standards into direct preferences over standards and preferences over the world prices that local standard choices imply for given tariff levels. This approach to representing government objectives enables us to isolate the terms-of-trade externality that tariff and local standard selections generate. We thus represent the objectives of the home and foreign governments by the general functions $W\left(s_{q}, s_{c}, p\left(\tau, \tilde{p}^{w}\right), \tilde{p}^{w}\right)$ and $W^{*}\left(s_{c}^{*}, s_{q}^{*}, p^{*}\left(\tau^{*}, \tilde{p}^{w}\right), \tilde{p}^{w}\right)$, respectively.

Notice that each government cares about the policy choices of its trading partner only indirectly, through the effects that these choices have on world prices. This structure reflects two underlying features of the environment set out above. First, our exclusion of global social concerns and international non-pecuniary externalities implies that governments have no direct reason to care about the policy choices of their trading partners. And second, the nature of international economic interaction ensures that all indirect effects of a government's policy choices on the economy of its trading partner are channeled through world prices. ${ }^{12}$

The only additional structure we place on $W$ and $W^{*}$ is that, holding its local price and its local standards fixed, each government achieves higher welfare when its terms of trade improve:

$$
\partial W\left(s_{q}, s_{c}, p, \tilde{p}^{w}\right) / \partial p^{w}<0 \text { and } \partial W^{*}\left(s_{q}^{*}, s_{c}^{*}, p^{*}, \tilde{p}^{w}\right) / \partial p^{w}>0 .
$$

\footnotetext{
${ }^{12} \mathrm{We}$ have argued that this second feature is important for understanding the structure of GATT rules more generally in Bagwell and Staiger (1999a, 1999b), where we observe that it will be preserved in a multi-country setting under GATT's principle of non-discrimination. We also note that additional channels can arise in environments where markets need not clear (Robinson, 1947) or positive mark-ups exist (Flam and Helpman,1987).
} 
We illustrate this structure with Figure 1, which depicts iso-local-price and iso-world-price loci as a function of home and foreign tariff levels given fixed local standards in each country. With local standard levels held fixed, an initial tariff pair $A \equiv\left(\tau, \tau^{*}\right)$ is associated with a domestic iso-local-price locus, $p(A) \rightarrow p(A)$, and an iso-world-price locus, $p^{w}(A) \rightarrow p^{w}(A) .{ }^{13}$ Also depicted is a second isoworld-price locus, $p^{w}(C) \rightarrow p^{w}(C)$, along which the world price is lower than at point A, indicating an improved terms of trade for the home country. A reduction in the world price that maintains the home-country local price is thus achieved (for fixed local standards) with the movement from point A to B, corresponding to a higher (lower) home-country (foreign-country) import tariff. We assume only that the home-country government values the implied income transfer.

To explore the generality of our representation of government objectives, we note that the structure imposed on government preferences by (3) states that a government would always strictly prefer a terms-of-trade improvement which allowed it to provide lump-sum distributions of additional income to its consumers, if this terms-of-trade improvement could be accomplished without altering any of the following: (i) the economy's local relative price and production standards faced by producers, and therefore the economy's production decisions; (ii) the level and distribution of factor income in the economy; or (iii) the economy's local relative price and consumption standards faced by consumers. From a political economy perspective, the assumption that a government would benefit from a terms-of-trade improvement of this nature seems benign in light of (ii), because the level and distribution of a country's factor income is being held fixed as its terms-of-trade improve under (3). Indeed, we have argued elsewhere (Bagwell and Staiger, 1996, 1999a) that each of the major approaches to the political economy of trade policy satisfies an assumption of this nature. This assumption would also seem to be satisfied in most environments where a government had a distinct reason to intervene in the production decisions of the economy, as it might for example if pollution was a by-product of the production process, because by (i) all production decisions in the economy are being held fixed as its terms-of-trade improve under (3). However, this assumption may be more restrictive in environments where a government has a distinct reason to intervene in the consumption

\footnotetext{
${ }^{13}$ Given the assumptions that Metzler and Lerner paradoxes are absent, the iso-local-price locus exhibits negative slope and the iso-world-price locus is positively sloped in Figure 1.
} 
decisions of the economy, as consumption decisions will be affected in the derivative defined by (3), i.e., national consumption is a function of $\tilde{p}^{w}$. It is possible, for instance, that negative externalities associated with consumption of a particular good could be exacerbated by the added consumption opportunities that additional tariff revenue affords, and if this effect is sufficiently strong then (3) might be violated. Nevertheless, condition (3) can always be checked in specific applications, and in a broad class of interesting environments it will be met.

\section{Non-cooperative Policy Choices}

We first characterize the non-cooperative Nash policy choices. If governments do not cooperate over policies, then for any set of foreign policy choices, the domestic government will choose its policies to solve:

(I). $\quad \operatorname{Max}_{\tau, s_{q}, s_{c}} W\left(s_{q}, s_{c}, p\left(\tau, \tilde{p}^{w}\right), \tilde{p}^{w}\right)$.

Similarly, for any set of domestic policies, the foreign government chooses its policies to solve:

(I*). $\quad \operatorname{Max}_{\tau^{*}, s_{q}^{*}, s_{c}^{*}} \quad W^{*}\left(s_{q}^{*}, s_{c}^{*}, p^{*}\left(\tau^{*}, \tilde{p}^{w}\right), \tilde{p}^{w}\right)$.

The Nash equilibrium choices are defined as a set of policies, $\left(\tau^{N}, s_{q}{ }^{N}, s_{c}{ }^{N}, \tau^{* N}, s_{q}^{* N}, s_{c}{ }^{* N}\right)$, which jointly satisfy the first order conditions associated with (I) and (I*): ${ }^{14}$

(4). $W_{s_{q}} \times\left(\frac{1}{\partial \tilde{p}^{w} / \partial s_{q}}\right)=-\left[\tau W_{p}+W_{p^{w}}\right]=W_{s_{c}} \times\left(\frac{1}{\partial \tilde{p}^{w} / \partial s_{c}}\right)$;

(5). $\quad W_{p}+\lambda W_{p^{w}}=0$;

(6). $\quad W_{s_{q}{ }^{*}}^{*} \times\left(\frac{1}{\partial \tilde{p}^{w} / \partial s_{q}{ }^{*}}\right)=-\left[\frac{1}{\tau^{*}} W_{p^{*}}^{*}+W_{p^{w}}^{*}\right]=W_{s_{c}}^{*} \times\left(\frac{1}{\partial \tilde{p}^{w} / \partial s_{c}{ }^{*}}\right)$; and

(7). $W_{p^{*}}^{*}+\lambda^{*} W_{p^{w}}^{*}=0$,

where, with the Metzler and Lerner paradoxes ruled out,

\footnotetext{
${ }^{14}$ For simplicity, we assume throughout that all policy choices correspond to interior solutions of the relevant maximization problems.
} 


$$
\lambda \equiv \frac{\left[\partial \tilde{p}^{w} / \partial \tau\right]}{[d p / d \tau]}<0 ; \quad \lambda^{*} \equiv \frac{\left[\partial \tilde{p}^{w} / \partial \tau^{*}\right]}{\left[d p^{*} / d \tau^{*}\right]}<0
$$

To interpret these conditions, consider (4) and (5), which define the home country's bestresponse policy choices as a function of foreign country policies. Observing that $-\left[\tau W_{p}+W_{p^{w}}\right]$ gives the impact on home government welfare of a small decrease in $\tilde{p}^{w}$ when the home tariff is held fixed, condition (4) dictates that the home government will set each of its local standards so that the direct effect on its welfare of a small change in a standard is just offset by the indirect effect on its welfare that the induced world price movement would imply. A similar interpretation, applied to the home government's tariff choice, holds for condition (5), which dictates that the home government will set its tariff so that the welfare effect of a small change in the local price induced by a change in its tariff is just offset by the indirect welfare effect that the world price movement induced by this tariff change would imply. Note also that, as $\lambda<0$ and as $W_{p}{ }<0$ by (3), condition (5) implies $W_{p}<0$, so that the home government is induced by the terms-of-trade effects of its policy choices to provide greater protection to its import-competing sector (and therefore a higher local relative price $p$ ) than it would choose to provide based on the local price effects of its tariff choice alone. Similarly, with $W_{p}<0$ by (5), condition (4) implies that the home government will be induced by the world-price effects of its policy choices to adopt local standards which are more favorable to its terms of trade than it would choose to adopt based on the direct impact of these standards on its welfare. Analogous statements apply with respect to the interpretations of (6) and (7).

\section{Efficient Policy Choices}

We next characterize efficient policy choices. Any efficient combination of policies, $\left(\tau^{E}, s_{q}^{E}, s_{c}^{E}, \tau^{* E}, s_{q}^{* E}, s_{c}^{* E}\right)$, will solve

(II). $\quad \operatorname{Max}_{\tau, s_{q}, s_{c}, \tau^{*}, s_{q}^{*}, s_{c}^{*}} W\left(s_{q}, s_{c}, p\left(\tau, \tilde{p}^{w}\right), \tilde{p}^{w}\right)$

$$
\text { s.t. } \quad W^{*}\left(s_{q}^{*}, s_{c}^{*}, p^{*}\left(\tau^{*}, \tilde{p}^{w}\right), \tilde{p}^{w}\right) \geq \bar{W}^{* E} \text {, }
$$

where $\bar{W}^{* E} \equiv W^{*}\left(s_{q}^{* E}, s_{c}{ }^{* E}, p^{*}\left(\tau^{* E}, \tilde{p}^{w E}\right), \tilde{p}^{w E}\right)$ and $\tilde{p}^{w E} \equiv \tilde{p}^{w}\left(\tau^{E}, s_{q}^{E}, s_{c}^{E}, \tau^{* E}, s_{q}{ }^{* E}, s_{c}^{* E}\right)$. The set of efficient 
policy combinations is defined as the set of solutions to the first order conditions associated with (II), which with some manipulation can be represented as:

$$
\begin{aligned}
& W_{s_{q}} \times\left(\frac{1}{\partial \tilde{p}^{w} / \partial s_{q}}\right)=W_{p} \times\left(\frac{\tilde{p}^{w}}{\partial \tilde{p}^{w} / \partial \tau}\right)=W_{s_{c}} \times\left(\frac{1}{\partial \tilde{p}^{w} / \partial s_{c}}\right) ; \\
& W_{s_{q}^{*}}^{*} \times\left(\frac{1}{\partial \tilde{p}^{w} / \partial s_{q}^{*}}\right)=W_{p^{*}}^{*} \times\left(\frac{-p^{*} / \tau^{*}}{\partial \tilde{p}^{w} / \partial \tau^{*}}\right)=W_{s_{c}^{*}}^{*} \times\left(\frac{1}{\partial \tilde{p}^{w} / \partial s_{c}{ }^{*}}\right) ; \text { and }
\end{aligned}
$$

$$
\left(1-A W_{p}\right)\left(1-A^{*} W_{p^{*}}^{*}\right)=1
$$

where $A \equiv(1-\tau \lambda) /\left(W_{p}+\lambda W_{p}{ }^{w}\right)$ and $A^{*} \equiv\left(1-\lambda^{*} / \tau^{*}\right) /\left(W_{p^{*}}^{*}+\lambda^{*} W_{p}^{*}{ }^{*}\right)$.

Conditions (8) and (9) can be interpreted as "national" efficiency conditions. Condition (8) says that, at an efficient policy combination, any small changes in $\tau, s_{q}$ and $s_{c}$ which together leave the equilibrium world price unchanged (and therefore do not affect foreign welfare) must leave home welfare unchanged as well. ${ }^{15}$ Similarly, condition (9) says that, at an efficient policy combination, any small changes in $\tau^{*}, s_{q}{ }^{*}$, and $s_{c}{ }^{*}$ which leave the equilibrium world price unchanged (and therefore do not affect home welfare) must leave foreign welfare unchanged as well. Note from (2) that unilateral changes in policy mix which leave the equilibrium world price unaltered must also leave equilibrium trade volumes unaltered. These conditions therefore ensure that each government is adopting an appropriate relative utilization of its policies in light of its own preferences and the equilibrium trade volume. Condition (10) can then be interpreted as the "international" efficiency condition, as it ensures that policies are set so that the equilibrium trade volume is indeed efficient.

Consider now the efficiency properties of the Nash equilibrium. Conditions (4) and (5) determine the best-response home-country policies to a set of foreign policies, and these two conditions together imply that (8) will be satisfied. Likewise, conditions (6) and (7) determine the

\footnotetext{
${ }^{15}$ For example, changes in $s_{q}$ and $\tau$ which keep $\tilde{p}^{w}$ fixed must satisfy $d \tau / d s_{q}=\left(-\partial \tilde{p}^{w} / \partial s_{q}\right) /\left(\partial \tilde{p}^{w} / \partial \tau\right)$. Efficiency requires that no change in home-government welfare can be induced by such policy changes, or that $W_{s_{q}}+W_{p}\left[\tilde{p}^{w} \times\left(-\partial \tilde{p}^{w} / \partial s_{q}\right) /\left(\partial \tilde{p}^{w} / \partial \tau\right)\right]=0$, which yields the first equality in (8).
} 
best-response foreign policies to a set of home-country policies, and these two conditions imply that (9) will be satisfied. Therefore, conditional on the Nash trade volume, each government is making efficient use of its policies. That is, each government is choosing a policy mix that satisfies its respective national condition for efficiency. But conditions (5) and (7) violate (10), and therefore Nash policies are inefficient because the international condition for efficiency is not met. Hence the inefficiency associated with Nash policy choices arises because of inefficient volumes of trade.

This point can be put more starkly by considering an alternative representation of the essential strategic interaction when governments set trade and domestic policies non-cooperatively. Let us define $\boldsymbol{M}$ as the set containing each domestic import demand schedule, $M_{x}\left(p^{w}\right)$, that is associated with some domestic policy combination (i.e., $M_{x}\left(p^{w}\right) \in \boldsymbol{M}$ if and only if there exists a $\left(\tau, s_{q}, s_{c}\right)$ such that $\left.M_{x}\left(s_{q}, s_{c}, p\left(\tau, p^{w}\right), p^{w}\right) \equiv M_{x}\left(p^{w}\right)\right)$. Similarly, let us define $\boldsymbol{M}^{*}$ as the set containing each foreign import demand schedule, $M_{y}^{*}\left(p^{w}\right)$, that is associated with some foreign policy combination. With the sets of feasible domestic and foreign import demand schedules defined by $\boldsymbol{M}$ and $\boldsymbol{M}^{*}$, respectively, we may now note that the Nash equilibrium policies when governments simultaneously and non-cooperatively set their tariffs and domestic standards, as defined by (4) through (7), will correspond as well to the Nash equilibrium policies in the following Two-Stage Non-cooperative Policy Game:

Stage 1: $\quad$ The domestic and foreign governments simultaneously select import demand schedules, $M_{x}\left(p^{w}\right)$ and $M_{y}^{*}\left(p^{w}\right)$, from the sets $\boldsymbol{M}$ and $\boldsymbol{M}^{*}$, respectively, and an equilibrium world price and trade volumes consistent with these import demand schedules are implied.

Stage 2: $\quad$ Each government selects a policy mix to deliver its implied import demand at the implied world price.

In this two-stage game, the equilibrium world price and trade volumes are determined in Stage 1, and in Stage 2 each government is therefore completely insulated from the remaining decisions of its trading partner. Consequently, in Stage 2 each government will make efficient use of its policies to deliver the import volume implied for it as the outcome of Stage 1, and hence (8) and (9) must be 
satisfied. But as the only strategic interaction between governments occurs in their Stage-1 selection of import demand schedules, and as the space of policy vectors for each government is mapped onto the set of its feasible import demand schedules, the Nash equilibrium selections in Stage 1 must satisfy (4) and (5) for the domestic government and (6) and (7) for the foreign government, and thus these selections must deliver the Nash trade volumes defined by (4) through (7) as well. Otherwise, the import demand schedules selected in Stage 1 could not be best responses: the domestic (foreign) government could do better by selecting the import demand schedule implied by the $\left(s_{q}, s_{c}, \tau\right)$ combination that solves (4) and (5) (the $\left(s_{q}^{*}, s_{c}^{*}, \tau^{*}\right)$ combination that solves (6) and (7)).

Therefore, the Nash equilibrium policies of the Two-Stage Non-cooperative Policy Game correspond to the Nash equilibrium policies when governments instead simultaneously and noncooperatively set their tariffs and domestic standards, as characterized by (4) through (7). From the structure of the Two-Stage Non-cooperative Policy Game, which by construction channels all strategic interaction between governments into the determination of equilibrium trade volumes, it is now transparent that the essential problem when governments choose trade and domestic policies non-cooperatively is that equilibrium trade volumes are inefficient.

Moreover, equilibrium trade volumes are inefficiently "low" in the sense that each government must secure additional market access from its trading partner in order to reach a mutually beneficial agreement. To see this, consider the net impact of foreign policy changes on home-country welfare, given by

$$
\frac{d W}{d \tau^{*}}+\frac{d W}{d s_{q}^{*}}+\frac{d W}{d s_{c}^{*}}=\left[\tau W_{p}+W_{p^{w}}\right] \times\left[\partial \tilde{p}^{w} / \partial \tau^{*}+\partial \tilde{p}^{w} / \partial s_{q}^{*}+\partial \tilde{p}^{w} / \partial s_{c}^{*}\right] .
$$

When the home-country government is on its reaction curves as defined by (4) and (5), we have

$$
\frac{d W}{d \tau^{*}}+\frac{d W}{d s_{q}^{*}}+\frac{d W}{d s_{c}^{*}}=\left[1-\tau^{R}\left(T^{*}\right) \lambda\right] \times W_{p}{ }^{w} \times\left[\partial \tilde{p}^{w} / \partial \tau^{*}+\partial \tilde{p}^{w} / \partial s_{q}^{*}+\partial \tilde{p}^{w} / \partial s_{c}^{*}\right]
$$

where to economize on notation we will henceforth where convenient use $T\left(T^{*}\right)$ to denote the 
vector of home-country (foreign) policies, i.e., $T \equiv\left(\tau, s_{q}, s_{c}\right)$ and $T^{*} \equiv\left(\tau^{*}, s_{q}^{*}, s_{c}^{*}\right)$.

We now introduce a measure of the change in market access that one country affords another through its policy choices. While in principle there are a variety of ways that changes in market access might be measured (e.g., changes in equilibrium import volumes), we will say that, at a world price $\hat{p}^{w}$, one foreign policy vector $T^{* 1}$ provides additional foreign-market access to the domestic country relative to a second vector of foreign policies $T^{* 2}$ if, at the world price $\hat{p}^{w}$, foreign import volume would be greater under the first vector of foreign policies, or

$$
M_{y}^{*}\left(s_{q}^{* 1}, s_{c}^{* 1}, p^{*}\left(\tau^{* 1}, \hat{p}^{w}\right), \hat{p}^{w}\right)>M_{y}^{*}\left(s_{q}^{* 2}, s_{c}^{* 2}, p^{*}\left(\tau^{* 2}, \hat{p}^{w}\right), \hat{p}^{w}\right) .
$$

This definition corresponds to the direction in which a country's policy changes would shift its import demand curve at a given world price: a country that affords additional (reduced) market access at a given world price engineers an outward (inward) shift of its import demand curve at that world price. According to this definition, and given our stability assumptions, a change in foreign policies that reduced foreign-market access at the initial equilibrium world price $\tilde{p}^{w}$ would lead to a rise in $\tilde{p}^{w}$. Hence, using (3) and (11) and recalling that $\lambda<0$, along the home government's reaction curves any small change in foreign policies that serves to reduce foreign-market access at the initial equilibrium world price must lower home-country government welfare.

Let us now say that a government secures additional market access from its trading partner if there exists a world price such that the trading partner's policy changes provide additional access to the trading partner's market (i.e., if the trading partner's import demand curve shifts out for at least some world price). We next proceed to establish that each government must secure additional market access from its trading partner in order to reach a mutually beneficial agreement. To show this, consider an agreement that specifies the domestic and foreign policy vectors $\left(T^{0}, T^{* 0}\right)$, and suppose that the foreign policy vector $T^{* 0}$ fails to offer additional foreign-market access relative to $T^{* N}$, the vector of Nash foreign policies. Then for any set of home-country policies $T^{0}$ specified in the agreement, we must have 


$$
\begin{aligned}
& W\left(s_{q}^{0}, s_{c}^{0}, p\left(\tau^{0}, \tilde{p}^{w}\left(T^{0}, T^{* 0}\right)\right), \tilde{p}^{w}\left(T^{0}, T^{* 0}\right)\right) \leq \\
& W\left(s_{q}^{R}\left(T^{* 0}\right), s_{c}^{R}\left(T^{* 0}\right), p\left(\tau^{R}\left(T^{* 0}\right), \tilde{p}^{w}\left(T^{R}\left(T^{* 0}\right), T^{* 0}\right)\right), \tilde{p}^{w}\left(T^{R}\left(T^{* 0}\right), T^{* 0}\right)\right)< \\
& W\left(s_{q}^{R}\left(T^{* N}\right), s_{c}{ }^{R}\left(T^{* N}\right), p\left(\tau^{R}\left(T^{* N}\right), \tilde{p}^{w}\left(T^{R}\left(T^{* N}\right), T^{* N}\right)\right), \tilde{p}^{w}\left(T^{R}\left(T^{* N}\right), T^{* N}\right)\right)= \\
& W\left(s_{q}{ }^{N}, s_{c}^{N}, p\left(\tau^{N}, \tilde{p}^{w}\left(T^{N}, T^{* N}\right)\right), \tilde{p}^{w}\left(T^{N}, T^{* N}\right)\right),
\end{aligned}
$$

so that the home-country government must be worse off under any agreement which specifies the foreign policy vector $T^{* 0} \cdot{ }^{16}$ A similar argument holds with respect to the foreign government. Hence, each government must secure additional market access from its trading partner in order to reach a mutually beneficial agreement. ${ }^{17}$

Finally, we may inquire into the reasons that governments are led through their unilateral decisions to restrict market access to inefficiently low levels. It should come as no surprise that the terms-of-trade consequences of unilateral policy choices represent one source of inefficiency. However, we now ask if there are additional distortions in this setting that keep governments from the efficiency frontier when making unilateral policy decisions. To explore this possibility, we follow our earlier work (Bagwell and Staiger, 1996, 1999a, 1999b) and imagine a world in which governments are not motivated by the terms-of-trade implications of their policy choices, and define the resulting politically optimal policies $\left(\tau^{p o}, s_{q}^{p o}, s_{c}^{p o}, \tau^{* p o}, s_{q}^{* p o}, s_{c}{ }^{* p o}\right)$ as the solution to

(12a). $W_{s_{q}}=0 ; W_{s_{c}}=0 ; W_{p}=0 ;$ and

(12b). $\quad W_{s_{q}^{*}}^{*}=0 ; W_{s_{c}^{*}}^{*}=0 ; W_{p^{*}}^{*}=0$.

The political optimum corresponds to the decisions governments would have made had they not been

\footnotetext{
${ }^{16}$ The strict inequality reflects the following logic. Beginning on the domestic reaction curve, with policies $\left(T^{R}\left(T^{* 0}\right), T^{* 0}\right)$, construct a policy path to the Nash policies, $\left(T^{N}, T^{* N}\right)$. Along this path, as $T^{*}$ is adjusted, set $T$ along the domestic reaction curve. Envelope arguments ensure that the resulting changes in $T$ have no first-order impact on $\mathrm{W}$. The $T^{*}$ changes, however, result in an increase in foreign-market access, causing a reduction in the equilibrium world price and thereby an increase in $W$ (by (11)).

${ }^{17}$ If in addition it is assumed that policy changes shift the import demand function in the same direction for all world prices, then a mutually beneficial trade agreement implies that each government secures additional equilibrium import volumes from its trading partner.
} 
concerned with exploiting their power over the terms of trade. But together (12a) and (12b) satisfy (8)-(10), and therefore politically optimal policies are indeed efficient. Thus, terms-of-trade manipulation is the problem that keeps Nash policy choices from reaching the efficiency frontier.

Of course, the political optimum is just one point on the efficiency frontier. More generally, any combination of policies satisfying (8)-(10) will be efficient, and the efficiency frontier will be defined by the set of all welfare pairs associated with policy combinations satisfying (8)-(10). We can summarize this discussion with:

Proposition 1: $\quad$ Nash policy choices are inefficient, and the incentive to manipulate the terms of trade is the source of the inefficiency. This incentive does not distort the policy mix chosen by each government, but Nash trade volume is inefficiently low, and each government must secure additional market access from its trading partner in order to reach a mutually beneficial agreement.

As Proposition 1 indicates, the terms-of-trade effects of unilateral policy choices are in fact the fundamental source of inefficiency that governments can correct through international negotiations in our formal setup, and it is therefore fair to say that contending with the terms-of-trade motives of governments is the focus of our subsequent analysis. Yet real governments rarely discuss in any explicit way such abstract notions as the terms-of-trade consequences of their decisions, and the attraction these governments have to international trade negotiations seems in any event to have less to do with enhancing efficiency than with a simple mercantilist desire for export markets. It is therefore worth pausing to interpret the terms-of-trade effects in more familiar terms, lest it be concluded that our framework, while general, is incapable of capturing the underlying forces at work in actual trade negotiations.

In this regard, it is important to observe that the terms-of-trade effects of a government's policy choices refer simply to its ability to shift the costs of its policies onto trading partners. This cost-shifting will occur, provided only that some of the incidence of a government's policies are 
borne by foreign exporters. Thus, for example, when a domestic government offers protection to an import-competing industry, some of the costs of that protection will be shifted abroad if foreign exporters accept lower (f.o.b.) prices for their sales in the domestic market. When such cost-shifting does occur, it is natural to expect that governments will be led to distort their policy choices, as they do not bear the whole cost of their decisions. ${ }^{18}$ Consequently, when viewed from the perspective of cost-shifting, terms-of-trade effects can be seen to represent a natural source of inefficiency associated with unilateral policy decisions. At the same time, these effects can also help to provide an economic explanation for the mercantilist orientation of actual negotiations, for as Proposition 1 indicates, they imply that each government is right to pin its hopes for a beneficial outcome of negotiations on its ability to gain enhanced access for its exporters to the markets of its trading partner (see Bagwell and Staiger, 1996, 1999a, 1999b for an elaboration on these points).

Returning now to the results summarized in Proposition 1, it is clear that direct negotiations over $\left(\tau, s_{q}, s_{c}, \tau^{*}, s_{q}^{*}, s_{c}^{*}\right)$ could allow governments to eliminate the inefficiencies present in the Nash equilibrium policy choices and move to a point on the efficiency frontier. But can direct negotiations over tariffs alone be structured so as to generate outcomes on the efficiency frontier as well? This is the question to which we now turn.

\section{Tariff Negotiations, Domestic Policies and GATT Rules}

In this section we consider the properties of bargaining outcomes under various negotiating structures. We begin in the next subsection by showing that negotiations over tariffs alone will lead

\footnotetext{
${ }^{18}$ This logic is sometimes raised in discussions of standards and trade policy, though it is not recognized as a termsof-trade argument. For example, in discussing the introduction of a new clean-air standard for gasoline, Roessler (1998, p. 222) observes: "A problem of WTO consistency would arise, however, if the domestic political constraints are such that a new standard would secure a parliamentary majority only if domestic gasoline is exempted from the standard for five years or, to put the issue in political-economy terms, if the cost of reducing pollution is initially borne only by nonvoting producers abroad." On cost-shifting motives and their relation to GATT more generally, see for example Jackson (1989, p. 19), who observes: "More subtle is the possibility that a national consensus could explicitly opt for a choice of policies that would not maximize wealth (in the traditionally measurable sense, at least), but would give preference to other non-economic goals...It can be argued that when a nation makes an 'uneconomic' choice, it should be prepared to pay the whole cost, and not pursue policies which have the effect of unloading some of the burdens of that choice on to other nations. In an interdependent world, paying the whole cost is not often easy to accomplish."
} 
to inefficient outcomes in the absence of any restraints on domestic policy choices. We then turn in the following subsections to the task of formally modeling and evaluating the impact of the restraints that GATT's existing rules place on these choices.

\section{A. Unrestricted Sovereignty over Local Standards}

We first consider "unrestricted sovereignty" over local standards. That is, we suppose that governments negotiate over tariffs, but that each government retains the unrestricted right to make unilateral adjustments to its local standards in the future. In effect, governments are free to cooperate over tariffs as they see fit, aware that local standards will then be set non-cooperatively. ${ }^{19}$ We show that such unrestricted sovereignty over local standards will lead to inefficiencies: starting from any point on the efficiency frontier, each government will have a unilateral incentive to manipulate its standards to reduce market access and enjoy the terms-of-trade benefit. Thus, the problem with granting governments unrestricted sovereignty over their local standards is that they will exploit this sovereignty to reduce their market access to inefficiently low levels. We now establish this formally.

Here and throughout this section we will follow GATT practice and depict the tariff commitments that countries make through negotiated agreement as bindings. The tariff bindings that a country agrees to in a GATT negotiation define the maximal tariff levels that it can legally apply. The legal right to set tariffs at an applied rate that is lower than the bound rate will be important later in this section, and so for consistency we allow for this possibility in this subsection as well.

Starting from any negotiated pair of tariff bindings, $\left(\bar{\tau}, \bar{\tau}^{*}\right)$, the home government will make use of its unrestricted sovereignty over local standards to solve the following problem:

$$
\begin{aligned}
& \text { (III). } \operatorname{Max}_{\tau, s_{q}, s_{c}} W\left(s_{q}, s_{c}, p\left(\tau, \tilde{p}^{w}\right), \tilde{p}^{w}\right) \\
& \text { s.t. } \quad \tau \leq \bar{\tau} .
\end{aligned}
$$

\footnotetext{
${ }^{19}$ Copeland (1990) explores an analogous negotiating structure. In a setting where governments are assumed to be national-income maximizers, he shows that tariff negotiations can be beneficial even if other instruments are "nonnegotiable." Our emphasis here is different: we simply wish to establish that this negotiating structure can not deliver governments to the efficiency frontier, and to evaluate why this is so, and we then move on to consider the efficiency properties of alternative negotiating structures.
} 
Comparing (III) with (I), it is clear that, if the negotiated tariff binding $\bar{\tau}$ does not constrain the home government's (applied) tariff choice, then its policy choices will satisfy the first-order conditions defining its unconstrained best-response, given by (4) and (5). ${ }^{20}$ Otherwise, the home government will set $\tau$ at its bound level, $\bar{\tau}$, and (4) will implicitly define $\left(s_{q}{ }^{R}\left(s_{q}{ }^{*}, s_{c}{ }^{*}, \tau^{*} ; \bar{\tau}\right), s_{c}{ }^{R}\left(s_{q}{ }^{*}, s_{c}{ }^{*}, \tau^{*} ; \bar{\tau}\right)\right)$.

Similarly, the foreign government will solve:

(III*). $\operatorname{Max}_{\tau^{*}, s_{q}^{*}, s_{c}^{*}} \quad W^{*}\left(s_{q}^{*}, s_{c}^{*}, p^{*}\left(\tau^{*}, \tilde{p}^{w}\right), \tilde{p}^{w}\right)$,

s.t. $\tau^{*} \leq \bar{\tau}^{*}$.

Comparing (III*) with (I*), it follows that, if the negotiated tariff binding $\bar{\tau}^{*}$ does not constrain the foreign government's (applied) tariff choice, then its policy choices will satisfy (6) and (7), the firstorder conditions defining its unconstrained best-response. Otherwise, the foreign government will choose to set $\tau^{*}$ at its bound level, $\bar{\tau}^{*}$, and (6) implicitly defines $\left(s_{q}^{* R}\left(s_{q}, s_{c}, \tau ; \bar{\tau}^{*}\right), s_{c}^{* R}\left(s_{q}, s_{c}, \tau ; \bar{\tau}^{*}\right)\right)$.

With equilibrium domestic and foreign policy choices then determined by the joint solutions to the relevant best-response functions, we can now state the next proposition:

Proposition 2: $\quad$ When governments are granted unrestricted sovereignty over their local standards, agreements to reduce tariff levels create an incentive to restrict market access and manipulate the terms of trade through domestic policy choices, and therefore tariff negotiations cannot achieve efficient outcomes.

Proof: The proof follows by observing that the domestic policy choices for any tariffs must satisfy (4) and (6). Efficiency, on the other hand, requires that conditions (8) through (10) are satisfied. But together with (4), efficiency condition (8) implies that the Nash condition (5) must also be satisfied, while together with (6), efficiency condition (9) implies that the Nash condition (7) must hold.

\footnotetext{
${ }^{20}$ This observation relies on a slight strengthening of our assumptions. We assume henceforth that $W\left(s_{q}, s_{c}, p\left(\tau, \tilde{p}^{w}\right), \tilde{p}^{w}\right)$ is globally concave in $\tau$, with an analogous assumption for foreign-government welfare.
} 
Hence, if efficiency conditions (8) and (9) are to hold, all four Nash conditions (4) through (7) must hold as well. But as established previously, this then implies that the final efficiency condition (10) must be violated.

QED

Intuitively, any attempt to use tariff negotiations alone to move from the inefficient Nash equilibrium to a point on the efficiency frontier will simply shift governments' incentives to manipulate their terms of trade on to their local standards choices, which will then be manipulated to reduce market access. Therefore, if governments negotiate tariff agreements but are granted unrestricted sovereignty over their local standards choices, inefficiencies will remain.

\section{B. GATT Rules: Non-violation Complaints}

If the problem with unrestricted sovereignty over local standards is that governments take advantage of their sovereignty to distort market access to inefficiently low levels, why not simply restrict their sovereignty to choices over policy combinations that do not reduce market access from the levels implied by tariff negotiations? This is the essential logic behind GATT's rules as they apply to the domestic policy choices of member governments. In this and the next subsection we explore how negotiated GATT bindings, the ability to renegotiate these bindings, and the right to bring nonviolation complaints can interact to address the inefficiencies identified above.

We will attempt to capture the implications of these rules formally in two steps. First, in this subsection we will introduce a simple two-stage tariff negotiating structure, in which the role of tariff bindings and the right to bring non-violation complaints are highlighted. In this simple structure, nonviolation complaints work to ensure that the level of market access commitments implied by tariff negotiations is not eroded by subsequent changes in domestic policies. This framework will serve to illustrate our main points. Then, in the next subsection, we will extend this two-stage negotiating structure to three stages, so as to allow governments as well the opportunity to renegotiate tariff bindings as GATT permits. This extended three-stage negotiating structure captures an essential feature of GATT's rules not captured by our simple two-stage structure, which is that these rules prevent erosion of the balance (but not necessarily the level) of market access commitments implied 
by tariff negotiations. We show that our main points arise as well in this more complicated negotiating environment.

We begin with some definitions. We will say that, for any recorded level of standards $\left(s_{q}^{0}, s_{c}^{0}\right)$ and $\left(s_{q}^{* 0}, s_{c}^{* 0}\right)$, a negotiated pair of tariff bindings $\left(\bar{\tau}, \bar{\tau}^{*}\right)$ implies a world price $\bar{p}^{w}$ and a level of domestic and foreign market access commitments, $\bar{M}_{x}$ and $\bar{M}_{y}^{*}$, respectively, where $\bar{p}^{w} \equiv \tilde{p}^{w}\left(\bar{\tau}, s_{q}^{0}, s_{c}^{0}, \bar{\tau}^{*}, s_{q}^{* 0}, s_{c}^{* 0}\right), \bar{M}_{x} \equiv M_{x}\left(s_{q}^{0}, s_{c}^{0}, p\left(\bar{\tau}, \bar{p}^{w}\right), \bar{p}^{w}\right)$ and $\bar{M}_{y}^{*} \equiv M_{y}^{*}\left(s_{q}^{* 0}, s_{c}^{* 0}, p^{*}\left(\bar{\tau}^{*}, \bar{p}^{w}\right), \bar{p}^{w}\right)$. With these definitions, we may now formally define the Two-Stage Tariff Negotiation Game. As tariff negotiations commence, local standards are initially recorded at their existing levels $\left(s_{q}^{0}, s_{c}^{0}\right)$ and $\left(s_{q}^{* 0}, s_{c}^{* 0}\right)$. Governments then proceed in two stages:

Stage 1: Governments bargain over tariffs, a pair of tariff bindings, $\left(\bar{\tau}, \bar{\tau}^{*}\right)$, is determined, and a world price and market access commitments, $\bar{p}^{w}, \bar{M}_{x}$ and $\bar{M}_{y}^{*}$, are implied.

Stage 2: $\quad$ Each government is entitled to make unilateral adjustments to its policy mix so long as (i) its tariff does not exceed its bound level, and (ii) its policy adjustments do not erode its implied market access commitments.

Stage 1 is meant to correspond to tariff negotiations under GATT's Article XXVIII bis, e.g., a GATT "Round" of tariff negotiations. Stage 2 reflects the freedom governments have to adjust unilaterally their trade and domestic policies subsequent to tariff negotiations. This freedom is constrained in two ways. First, the applied tariff that each government implements cannot exceed its bound rate as determined in Stage 1. This reflects the legal commitment embodied in a GATT binding. And second, governments are prevented from altering their policy mix in a way that would erode their implied market access commitments from Stage 1. This reflects the constraint imposed on each government by the ability of its trading partner to bring a non-violation complaint under Article XXIII, and thereby to seek redress if it does alter its policies in such a way as to reduce access to its markets below that implied by the outcome of Stage 1. In measuring the implied market access to which governments will be held, we use the definition of market access changes introduced earlier, and evaluate these changes at the implied world price. Hence, we assume that the prospect of nonviolation Article XXIII complaints prevents each government from adjusting its policies in Stage 2 
in a way that would reduce its market access at $\bar{p}^{w}$, the implied world price from Stage $1 .^{21}$

To determine the properties of this two-stage procedure, consider first the problem that each government will solve in the second stage. Starting from $\left(\bar{\tau}, s_{q}^{0}, s_{c}^{0}, \bar{\tau}^{*}, s_{q}^{* 0}, s_{c}^{* 0}\right)$, the home-country government is permitted to adjust its policy mix subsequent to tariff negotiations to solve:

(IV). $\operatorname{Max}_{\tau, s_{q}, s_{c}} W\left(s_{q}, s_{c}, p\left(\tau, \tilde{p}^{w}\right), \tilde{p}^{w}\right)$

s.t. (i). $\quad \tau \leq \bar{\tau}$; and

(ii). $\quad M_{x}\left(s_{q}, s_{c}, p\left(\tau, \bar{p}^{w}\right), \bar{p}^{w}\right) \geq \bar{M}_{x}$.

The first-order conditions associated with (IV) define the domestic government's best-response policy mix for any set of foreign policies. Likewise, the foreign-country government is permitted to adjust its policy mix subsequent to tariff negotiations to solve:

$\left(\mathrm{IV}^{*}\right) . \operatorname{Max}_{\tau^{*}, s_{q}^{*}, s_{c}^{*}} \quad W^{*}\left(s_{q}^{*}, s_{c}^{*}, p^{*}\left(\tau^{*}, \tilde{p}^{w}\right), \tilde{p}^{w}\right)$

$$
\begin{array}{lll}
\text { s.t. } & \left(\mathrm{i}^{*}\right) . & \tau^{*} \leq \bar{\tau}^{*} \text {; and } \\
& \left(\mathrm{ii}^{*}\right) . & M_{y}^{*}\left(s_{q}^{*}, s_{c}^{*}, p^{*}\left(\tau^{*}, \bar{p}^{w}\right), \bar{p}^{w}\right) \geq \bar{M}_{y}^{*} .
\end{array}
$$

The first-order conditions associated with $\left(\mathrm{IV}^{*}\right)$ define the foreign government's best-response policy mix given a set of domestic policies. Given a set of recorded standards and a Stage-1 negotiation outcome, the equilibrium Stage- 2 domestic and foreign policy choices will then be determined by the

\footnotetext{
${ }^{21}$ This presumes that the right to bring Article XXIII complaints extends beyond trade volumes to prices as well. If market access assurances were simply a matter of assured equilibrium import volumes, then the strong properties associated with non-violation complaints which we establish below would have to be qualified (see Winters, 1997, Srinivasan, 1998, and Bagwell and Staiger, 1999b). However, this presumption finds some support in the legal arguments surrounding Article XXIII disputes. For example, a GATT Panel Report regarding the Article XXIII (violation) complaint brought by the United States and others against the EC "banana regime" stated: "The Hawaiian producers had expressed their concerns that the EC banana regime was lowering the price of bananas in the free market, adversely affecting their ability to continue to produce and potentially export bananas." (WTO, 1999).
} 
joint solution to these best-response functions.

Notice that, if the foreign government chooses $\left(\tau^{*}, s_{q}^{*}, s_{c}^{*}\right)$ to meet its market access commitments exactly, so that (ii*) holds with equality, then (1) and (2) imply that domestic policies $\left(\tau, s_{q}, s_{c}\right)$ satisfy constraint (ii) with equality if and only if $\tilde{p}^{w}\left(\tau, s_{q}, s_{c} ; \tau^{*}, s_{q}^{*}, s_{c}^{*}\right)=\bar{p}^{w}$. Moreover, under our stability assumptions, (ii) is satisfied with strict inequality if and only if the associated domestic policy choices imply an equilibrium world price $\tilde{p}^{w}\left(\tau, s_{q}, s_{c} ; \tau^{*}, s_{q}^{*}, s_{c}^{*}\right)$ which exceeds $\bar{p}^{w}$. Hence, whenever the foreign government chooses to meet its market access commitments exactly, the Stage2 problem for the home government may be rewritten as:

(IV'). $\operatorname{Max}_{\tau, s_{q}, s_{c}} W\left(s_{q}, s_{c}, p\left(\tau, \tilde{p}^{w}\right), \tilde{p}^{w}\right)$

$$
\begin{array}{ll}
\text { s.t. } & \text { (i). } \\
& \tau \leq \bar{\tau} \text {; and } \\
& \text { (ii'). } \tilde{p}^{w}\left(\tau, s_{q}, s_{c} ; \tau^{*}, s_{q}^{*}, s_{c}^{*}\right) \geq \bar{p}^{w} .
\end{array}
$$

Evidently, in this case the prospect of an Article XXIII non-violation complaint against it is sufficient to prevent the home government from altering its policies subsequent to tariff negotiations in a way that would improve its terms of trade. Recalling now from Proposition 1 that terms-of-trade manipulation is the underlying source of inefficiency that negotiations can correct, and from Proposition 2 that an agreement on tariffs alone will shift the incentive to manipulate the terms of trade on to domestic standards choices, it may be anticipated that the ability to bring non-violation complaints can have an important efficiency-enhancing role. ${ }^{22}$

To explore this role, we ask whether points on the efficiency frontier can be reached with appropriate Stage-1 outcomes, in light of the Stage-2 adjustments that may be anticipated. Given an

\footnotetext{
${ }^{22}$ In this regard, the role of non-violation complaints that we highlight here bears a relationship to the well-known results of Kemp and Wan (1976). In their classic paper, Kemp and Wan showed how the membership of a customs union could always be increased in such a way as to raise the national income of member countries without reducing the national income of any non-member country. The customs union need only adjust its (common) external tariffs to neutralize the impact of the addition of new members on the external terms of trade with remaining non-members.
} 
existing set of recorded standards, we will say that a policy combination can be implemented under tariff negotiations if there exists a pair of tariff bindings such that this policy combination corresponds to a Nash equilibrium in Stage 2 of the Two-Stage Tariff Negotiation Game. ${ }^{23}$

Let us consider, then, a combination of policies $\left(\tau^{E}, s_{q}^{E}, s_{c}^{E}, \tau^{* E}, s_{q}^{* E}, s_{c}^{* E}\right)$ satisfying (8)-(10), and ask whether, given a set of recorded standards, this efficient policy combination can be implemented under tariff negotiations. Associated with this efficient policy combination will be domestic and foreign import volumes, which we denote by $M_{x}^{E}$ and $M_{y}^{* E}$, respectively, and a world price which we denote by $\tilde{p}^{w E}$. Suppose, then, that Stage-1 negotiations were to result in a pair of tariff bindings $\left(\bar{\tau}^{E}, \bar{\tau}^{* E}\right)$ defined implicitly by $\bar{M}_{x}=M_{x}^{E}$ and $\bar{M}_{y}^{*}=M_{y}^{* E}$, and note that these bindings would imply a world price $\bar{p}^{w}=\tilde{p}^{w E}$. Suppose further, for the moment, that $\bar{\tau}^{E} \geq \tau^{E}$ and $\bar{\tau}^{* E} \geq \tau^{* E}$, so that these bindings are set above the tariff levels associated with the efficient policy combination under consideration. Then it follows from (IV) and (IV*) that $\left(\tau^{E}, s_{q}^{E}, s_{c}{ }^{E}, \tau^{* E}, s_{q}{ }^{* E}, s_{c}{ }^{* E}\right)$ can be implemented under tariff negotiations, provided only that at this efficient policy combination we have $d W / d \tau^{*}<0$ and $d W^{*} / d \tau<0$ (i.e., provided that, at this efficient policy combination, each government would be hurt by a unilateral increase in the tariff of its trading partner). To see this, note first that it is feasible for the home government to select $\left(\tau^{E}, s_{q}^{E}, s_{c}^{E}\right)$ and for the foreign government to select $\left(\tau^{* E}, s_{q}^{* E}, s_{c}^{* E}\right)$ in Stage 2. And second, note that these selections are indeed best-responses, since the resulting policy choices (a) are efficient, (b) satisfy $d W / d \tau^{*} \equiv\left[\tau W_{p}+W_{p^{w}}\right] \partial \tilde{p}^{w} / \partial \tau^{*}<0$ and $d W^{*} / d \tau \equiv\left[W_{p^{*}}^{*} / \tau^{*}+W_{p^{w}}^{*}\right] \partial \tilde{p}^{w} / \partial \tau<0$, which implies in turn that $\left[\tau W_{p}+W_{p^{w}}\right]<0$ and $\left[W_{p^{*}}^{*} / \tau^{*}+W_{p^{w}}^{*}\right]>0$, and (c) meet the home and foreign market access commitments exactly. Consequently, to do better for itself, a government would have to hurt its trading partner by (a), and therefore by (b) would have to worsen the terms of trade of its trading partner from $\bar{p}^{w}$, but by (c) would be prevented from doing so as a result of constraint (ii') or its foreign-government analogue.

Hence, any efficient combination of policies $\left(\tau^{E}, s_{q}{ }^{E}, s_{c}{ }^{E}, \tau^{* E}, s_{q}{ }^{* E}, s_{c}{ }^{* E}\right)$ satisfying the restrictions (i) $d W / d \tau^{*}<0$ and $d W^{*} / d \tau<0$, and (ii) $\bar{\tau}^{E} \geq \tau^{E}$ and $\bar{\tau}^{* E} \geq \tau^{* E}$ can be implemented under tariff

\footnotetext{
${ }^{23}$ We do not explore conditions for the uniqueness of the Stage-2 Nash equilibrium.
} 
negotiations. We now consider the nature of these restrictions in more detail, so as to better assess the limitations associated with attempts to implement efficient outcomes with tariff negotiations.

Consider first the restriction that $d W / d \tau^{*}<0$ and $d W^{*} / d \tau<0$. By (3), this restriction will certainly be met at the politically optimal policy combination defined by (12a) and (12b), as at this combination of policies $W_{p}=0=W_{p}{ }^{*}$ and hence world price effects alone dictate how one government feels about a tariff increase by its trading partner. Clearly, this restriction will be met for a range of efficient policy combinations around the political optimum as well. In fact, it is straightforward to show that a sufficient condition for this restriction to be met by an efficient policy combination is that the efficient policies require each government to bind its tariff below its best-response tariff. ${ }^{24}$ This first restriction will be met, then, for all efficient policy combinations at which each government agrees to restrain the unilateral desire to raise its tariff. Given the nature of GATT bindings (i.e., defining a maximal tariff level), a focus on efficient policy combinations that satisfy this property does not seem particularly limiting. Therefore, in light of GATT's approach to tariff bindings, we will henceforth refer to efficient policy combinations that share this property as efficient combinations of tariff bindings and standards policies, and we will focus on the feasibility of implementing such policy combinations under tariff negotiations for the remainder of the paper.

Consider next the restriction that $\bar{\tau}^{E} \geq \tau^{E}$ and $\bar{\tau}^{* E} \geq \tau^{* E}$. To explore the nature of this additional restriction, observe that $\bar{\tau}^{E}$ and $\bar{\tau}^{* E}$ must satisfy, respectively,

$$
M_{x}\left(s_{q}^{0}, s_{c}^{0}, p\left(\bar{\tau}^{E}, \tilde{p}^{w E}\right), \tilde{p}^{w E}\right)=M_{x}\left(s_{q}^{E}, s_{c}^{E}, p\left(\tau^{E}, \tilde{p}^{w E}\right), \tilde{p}^{w E}\right)
$$

and

$$
M_{y}^{*}\left(s_{q}^{* 0}, s_{c}^{* 0}, p^{*}\left(\bar{\tau}^{* E}, \tilde{p}^{w E}\right), \tilde{p}^{w E}\right)=M_{y}^{*}\left(s_{q}^{* E}, s_{c}^{* E}, p^{*}\left(\tau^{* E}, \tilde{p}^{w E}\right), \tilde{p}^{w E}\right)
$$

where we have used the definitions of $\bar{\tau}^{E}$ and $\bar{\tau}^{* E}$ and the fact that the implied world price satisfies $\bar{p}^{w}=\tilde{p}^{w E}$. As the first expression makes clear, if $\bar{\tau}^{E} \geq \tau^{E}$, then existing domestic standards are being

\footnotetext{
${ }^{24}$ This can be seen by noting that, if the home (foreign) government sets its tariff below its best-response tariff, then we must have $d W / d \tau>0\left(d W^{*} / d \tau^{*}>0\right)$ and efficiency then requires $d W^{*} / d \tau<0$ and $d W / d \tau^{*}<0$.
} 
set in a way that encourages market access at $\tilde{p}^{w E}$ relative to the efficient choice of standards. A similar interpretation from the foreign country's perspective holds for the condition that $\bar{\tau}^{* E} \geq \tau^{* E}$.

Whether the restriction that $\bar{\tau}^{E} \geq \tau^{E}$ and $\bar{\tau}^{* E} \geq \tau^{* E}$ will be met depends, therefore, on whether existing standards are being set in a way that encourages market access at $\tilde{p}^{w E}$ relative to the efficient choice of standards. This will in turn depend on where governments are starting from (the existing standards levels) and where they wish to go (the particular point on the efficiency frontier). But the circumstances under which this restriction will not be met, namely, that governments face the prospect of tariff negotiations from a starting point in which their existing standards are set in a way that discourages access to their markets relative to efficient standards policy, seem quite plausible. Such circumstances would certainly be suggested by Proposition 2. In this event, in order to achieve efficient trade volumes through tariff negotiations, each government would have to offer the appropriate level of market access to its trading partner by agreeing to bind its tariff at a level below the tariff that would be efficient in combination with its efficient standards choices, and in light of these bindings the resulting mix of policies could not then achieve efficiency. And if bindings were instead set at or above the level of efficient tariffs, the implied market access commitments would be insufficient to induce governments to select efficient trade volumes. ${ }^{25}$ Hence, we interpret this second restriction as placing more serious limitations on the ability to implement efficient outcomes with tariff negotiations.

With interpretations of these restrictions in hand, we now summarize the results of this subsection with:

\footnotetext{
${ }^{25}$ This last point relies on a slight further strengthening of our assumptions. We assume henceforth that $W\left(s_{q}, s_{c}, p\left(\tau, \tilde{p}^{w}\right), \tilde{p}^{w}\right)$ is globally concave in $s_{q}$ and $s_{c}$, with an analogous assumption for foreign-government welfare. With this, suppose for example that bindings were set at the efficient tariff levels, and note that in this case the implied market access commitments would be below the efficient levels. Suppose as well that the foreign government set the efficient foreign policies in stage 2. It may now be seen that the domestic government's best response can not be the corresponding efficient domestic policies. This follows, with global concavity of $W$ in $s_{q}$ and $s_{c}$, from Proposition 2 , which implies that, even with its tariff bound at the efficient level, the domestic government would wish to alter its standards policies from their efficient levels so as to restrict domestic-market access below the efficient level, and it could do so in this case without violating its market access commitments.
} 
Proposition 3: $\quad$ Consider any efficient combination of tariff bindings and standards policies. This efficient policy combination can be implemented under tariff negotiations if and only if existing standards have been set by each government in a way that encourages access to its markets relative to the efficient standards policy.

It is clear from a comparison of Propositions 2 and 3 that the prospect of non-violation complaints restricts sovereignty over domestic policy choices in a way that, in some circumstances, can allow governments to reach the efficiency frontier with tariff negotiations alone. In this manner, GATT's existing rules can be seen to contribute toward a solution to the problems associated with standard setting while maintaining some sovereignty over standards choices for its member governments. It is also clear from Proposition 3, however, that in combination with tariff bindings the prospect of non-violation complaints does not leave governments with sufficient sovereignty over their policy choices to reach the efficiency frontier in all circumstances. We will explore the possibility of modifications to GATT's rules that might address these limitations in the penultimate section of the paper. Before doing this, however, we turn in the next subsection to consider an important feature of GATT's rules not captured by the Two-Stage Tariff Negotiation Game introduced above.

\section{GATT Rules: Reciprocity}

In the Two-Stage Tariff Negotiation Game of the previous subsection, governments are not permitted to modify their Stage-1 tariff bindings. In combination with the prospect of non-violation complaints, this has the effect of ensuring that the level of market access commitments implied by tariff negotiations will not be eroded by subsequent changes in domestic policy. In reality, however, GATT's rules $d o$ provide governments with the right to modify their tariff bindings. Indeed, the central function of Article XXIII non-violation complaints is not to prevent governments from ever modifying their market access commitments, but to induce them to do so explicitly by renegotiating their bindings under the rules of GATT (see also note 3 ). These rules are provided in Article XXVIII, which sets out the procedures under which a government may lawfully modify or withdraw its tariff bindings, as well as the rights of its trading partners in this event. Under these procedures, a government may choose unilaterally to raise a tariff binding, with the knowledge that its trading 
partners will then be permitted to withdraw reciprocal concessions of their own. Hence, while the tariff bindings that governments negotiate do imply levels of market access commitments, what is secured by GATT tariff negotiations in light of the ability to renegotiate is not the level but rather the balance of these commitments, as defined by reciprocity. In this subsection, we consider an extended negotiating structure in order to capture this essential feature of GATT's rules.

Accounting for the renegotiation provisions of GATT may also be essential for a complete understanding of the problems faced by governments as they liberalize tariffs under GATT rules and contemplate their own domestic standards choices. In fact, GATT legal scholars (e.g., Enders, 1996, Roessler, 1998) often describe GATT's renegotiation provisions as an already-available answer to the perceived conflict between GATT market access commitments and strong labor and environmental standards. For example, in discussing possible routes that GATT might consider in an effort to allow governments greater leeway to respond to the constraints imposed by these race-tothe-bottom-type issues, Roessler (1998) observes:

One legal method...would be to permit [governments] to individually vary their market-access commitments in accordance with those constraints. That method is already available. The market-access commitments under the WTO agreements are made by product (GATT), by sector (GATS), or by entity (Agreement on Government Procurement). The schedules of commitments of WTO members therefore vary significantly. Moreover, WTO members are entitled to renegotiate their commitments. Both during the process of negotiating the commitments and after their acceptance, WTO members thus have the possibility to adjust their trade obligations...However, this adjustment takes place at the time when market-opening commitments are negotiated or after a renegotiation based on reciprocity, and therefore maintains the balance of rights and obligations among members.

...Given the right of each member to adjust its market-access commitments to its perception of these issues, the real issue is whether the WTO members should be able to react to the external repercussions of their own domestic policy choices by unilaterally withdrawing their market-access commitments or whether they should be able to do so only by renegotiating their commitments. A multilateral trade order based on the rule of law cannot but be based on the principle of renegotiation. (Roessler, 1998, p. 224).

An important question is therefore whether the remaining impediments to efficient outcomes that we have identified in the Two-Stage Tariff Negotiation Game might be removed once GATT's renegotiation provisions are properly accounted for. This provides a second reason for studying an extended negotiation structure which incorporates this feature.

As we have argued elsewhere (Bagwell and Staiger, 1999a), mutual changes in tariffs that 
conform to reciprocity - equal changes in import volumes across trading partners - will leave the terms of trade unchanged. ${ }^{26}$ Hence, Article XXVIII provides each government with the unilateral right to reduce the level of its market access commitments by raising the level of its tariff bindings, but the reciprocal actions of its trading partners permitted under Article XXVIII will ensure that this unilateral right does not extend to altering the terms of trade. In our earlier paper we explored the consequences of this rule of renegotiation for negotiated tariff agreements, and showed that it had the effect of guiding governments in their negotiations toward efficient politically optimal tariffs. However, we did not explore the possibility that governments would be choosing domestic policies as well. By extending the Two-Stage Tariff Negotiation Game considered above to allow for the possibility of Article XXVIII renegotiation, we may investigate how the results of the previous subsection and the results of our earlier paper each extend to a richer policy environment.

Formally, we now extend our negotiation structure to three stages with the introduction of a "renegotiation" stage (corresponding to Article XXVIII) between stages 1 and 2 of the Two-Stage Tariff Negotiation Game, where any renegotiation satisfies the restriction of reciprocity as outlined above, and thus results in mutual changes in tariff bindings that preserve the implied world price from the first stage. To ensure that the renegotiation process achieves eventual resolution (and in line with Article XXVIII), we assume that, if governments fail to agree on a renegotiated set of bindings, then the bindings that are implemented at the end of this stage are those that imply the greatest level of market access consistent with the restriction of reciprocity and the requirement that no government is asked to provide greater market access than would be implied by its proposal in the renegotiation stage.

We start with some definitions. Given a world price $\bar{p}^{w}$ that is implied by the outcome of the first stage of negotiations, we will say that a renegotiated pair of tariff bindings satisfies the restriction of reciprocity if the pair of bindings also implies the original world price. If in the renegotiation stage

\footnotetext{
${ }^{26}$ Formally, we say that the changes in trade volumes associated with the change from one policy vector $\left(T^{0}, T^{* 0}\right)$ to another $\left(T^{1}, T^{* 1}\right)$ conform to reciprocity if $\tilde{p}^{w 0}\left[M_{x}^{1}-M_{x}^{0}\right]=\left[E_{y}^{* 1}-E_{y_{1}}^{* 0}\right]$. Utilizing the trade balance condition at $\tilde{p}^{w 0}$ and again at $\tilde{p}^{w l}$ allows this condition to be rewritten as $\left[\tilde{p}^{w l}-\tilde{p}^{w 0}\right] M_{x}^{1}=0$, which implies that the terms of trade must remain unchanged.
} 
the domestic government proposes to bind its tariff at $\hat{\tau}$ and the foreign government proposes to bind its tariff at $\hat{\tau}^{*}$, then we will say that the domestic and foreign governments' proposed market access levels are, respectively, $M_{x}\left(s_{q}^{0}, s_{c}^{0}, p\left(\hat{\tau}, \bar{p}^{w}\right), \bar{p}^{w}\right)$ and $M_{y}^{*}\left(s_{q}^{* 0}, s_{c}^{* 0}, p^{*}\left(\hat{\tau}^{*}, \bar{p}^{w}\right), \bar{p}^{w}\right)$. Under the restriction of reciprocity the binding proposed by one government will define a reciprocal binding for its trading partner. We thus define the domestic government's reciprocal foreign binding, $\tau^{*}=\tau^{*}\left(\hat{\tau}, \bar{p}^{w} ; s_{q}^{0}, s_{c}^{0}, s_{q}^{* 0}, s_{c}^{* 0}\right)$, and the foreign government's reciprocal domestic binding, $\tau=\tau\left(\hat{\tau}^{*}, \bar{p}^{w} ; s_{q}^{0}, s_{c}^{0}, s_{q}^{* 0}, s_{c}^{* 0}\right)$, by the requirements that $\left(\hat{\tau}, \tau^{*}\left(\hat{\tau}, \bar{p}^{w} ;\right)\right)$ and $\left(\tau\left(\hat{\tau}^{*}, \bar{p}^{w} ;\right), \hat{\tau}^{*}\right)$ satisfy the restriction of reciprocity. We may then say that the proposed bindings, $\hat{\tau}$ and $\hat{\tau}^{*}$, agree if they yield the same pair of bindings along the iso-world-price locus: $\left(\hat{\tau}, \tau^{*}\left(\hat{\tau}, \bar{p}^{w} ; \cdot\right)\right)=\left(\tau\left(\hat{\tau}^{*}, \bar{p}^{w} ; \cdot\right), \hat{\tau}^{*}\right)$. When the proposed bindings do not agree, the pair of bindings that is implemented satisfies the restriction of proposed market access limits if the domestic market access implied under this pair of bindings is no greater than the domestic government's proposed market access, and the foreign market access implied under this pair of bindings is likewise no greater than the foreign government's proposed market access. This final restriction formalizes the idea that neither government can be forced to provide greater access to its markets than that implied by its own proposal in the renegotiation stage.

With these definitions, we may now formally define the Three-Stage TariffNegotiation Game. As tariff negotiations commence, local standards are initially recorded at their existing levels $\left(s_{q}^{0}, s_{c}^{0}\right)$ and $\left(s_{q}^{* 0}, s_{c}^{* 0}\right)$. Governments then proceed in three stages:

Stage 1: $\quad$ Governments bargain over tariffs, a pair of tariff bindings, $\left(\bar{\tau}, \bar{\tau}^{*}\right)$, is determined, and a world price, $\bar{p}^{w}$, is implied.

Stage 2: $\quad$ The domestic government proposes a domestic tariff binding, $\hat{\tau}$, at the same time that the foreign government proposes a foreign tariff binding, $\hat{\tau}^{*}$. If the proposals agree, then they are implemented as the outcome of the negotiation. If the proposals do not agree, then the bindings that are implemented as the outcome of the negotiation are those which imply the greatest market access while satisfying the restrictions of reciprocity and proposed market access limits.

Stage 3: $\quad$ Each government is entitled to make unilateral adjustments to its policy mix so long as ( $i$ ) its tariff does not exceed its bound level, and (ii) its policy adjustments do not erode its implied market access commitments. 
Effectively, the Three-Stage Tariff Negotiation Game has governments determining the balance of market access commitments - and therefore the terms of trade - in Stage 1 negotiations, the level of market access commitments in Stage 2 renegotiations, and the policy mix with which each government will deliver its market access commitments in the unilateral decisions of Stage 3. We will say that a policy combination can be implemented under reciprocal tariff negotiations if, given the existing standards, there exists a $\bar{p}^{w}$ such that the stage 2-3 subgame yields this efficient combination outcome as a subgame perfect Nash equilibrium.

In the Appendix, we show that an efficient policy combination cannot be implemented under reciprocal tariff negotiations if this policy combination is not politically optimal. Intuitively, attempts to implement an efficient combination of policies that are not politically optimal will fail under reciprocal tariff negotiations because, at such a policy combination, some country will desire less trade volume if it can achieve this reduction in trade volume without altering the world price, and the Stage-2 ability to renegotiate its tariff bindings subject to reciprocity provides it with just such an opportunity. We further establish that reciprocal tariff negotiations cannot implement a politically optimal combination of policies if existing standards have been set by either government in a way that discourages access to its markets relative to the efficient politically optimal standards policy. In this case, the problem is that, in light of the existing standards, the tariff bindings necessary to induce the efficient levels of trade volume in Stage 2 would prevent governments from achieving in Stage 3 the politically optimal tariff levels once standards were also adjusted to their politically optimal levels. Finally, with two additional conditions we establish that reciprocal tariff negotiations can implement a politically optimal combination of policies if existing standards have been set by each government in a way that encourages access to its markets relative to the efficient politically optimal standards policy. The first condition is that, at the political optimum, each government's welfare is no less than the welfare level it could achieve in the absence of negotiations (i.e., in a non-cooperative equilibrium) if it could simply commit to a unilateral increase (beyond the Nash equilibrium level) in the market access it offered to its trading partner. This amounts to a slight additional tightening from our earlier 
focus on efficient points at which each government is below its best-response tariff. ${ }^{27}$ The second additional condition is that tariffs and domestic standards are sufficiently close substitutes for meeting market access objectives. Together, these two additional conditions assure that, when existing standards encourage market access relative to efficient politically optimal standards, politically optimal policies may indeed be implemented under reciprocal tariff negotiations.

Formally, we may now state:

Proposition 4: An efficient combination of tariff bindings and standards policies can be implemented under reciprocal tariff negotiations if and only if (a) it consists of a politically optimal combination of tariffs and local standards, and (b) existing standards have been set by each government in a way that encourages access to its markets relative to the efficient politically optimal standards policy.

\section{Proof: (See Appendix).}

As with Proposition 3, it is clear from Proposition 4 that the prospect of non-violation complaints restricts sovereignty over domestic policy choices in a way that can allow governments to reach the efficiency frontier with tariff negotiations alone, but in combination with tariff bindings the prospect of non-violation complaints does not leave governments with sufficient sovereignty over their policy choices to reach the efficiency frontier in all circumstances. We consider modifications to GATT's

\footnotetext{
${ }^{27}$ More formally, we assume that the political optimum provides each government with at least as much welfare as it could achieve in the Two-Stage Non-cooperative Policy Game were it able to select in Stage 1 any point on the Stage-1 reaction function of its trading partner which left it below its own Stage-1 reaction function. Assuming that each government prefers the political optimum to Nash, this first additional condition will be met if the Stage-1 reaction functions of the Two-Stage Non-cooperative Policy Game slope down (i.e., if, starting from a point on its reaction function, the best response to an outward shift of the import demand schedule of one's trading partner measured at the world price implied by the original policies - is to shift inward one's own import demand schedule at this original world price), as then committing to a market-opening policy change could only reduce welfare below the Nash level. It is easily shown that this condition will also be met if the Stage-1 reaction curves slope up and countries are not too asymmetric.
} 
existing rules that might address this potential shortcoming in the next section.

\section{Tariff Negotiations and National Sovereignty}

Our analysis thus far has identified circumstances under which tariff negotiations structured along current GATT principles can allow governments to achieve globally efficient trade and domestic policies. These circumstances, however, appear to be limited in important ways. This is reflected in both Propositions 3 and 4, where an important impediment to achieving globally efficient policies will arise whenever either government has set the level of its existing domestic standards in a way that discourages access to its markets relative to efficient levels. In this section we consider the source of this impediment in greater detail, in order to identify modifications to GATT rules that might remove it.

As Propositions 3 and 4 indicate, GATT's rules can deliver globally efficient outcomes, so long as two requirements are met: first, governments must be able to secure market access commitments through tariff negotiations; and second, each government must be able to choose unilaterally and without external constraints the best way to meet its market access commitments. We have argued that, once a level of bindings is established, the prospect of non-violation complaints will secure the balance of the implied market access commitments against erosion as a result of future changes in either country's domestic policies. This is captured by constraints (ii) and (ii*) in (IV) and $\left(\mathrm{IV}^{*}\right)$, respectively, which imply that each government is free to adjust unilaterally its domestic policies in a way that reduces access to its markets if it compensates with a market-access-stabilizing tariff cut.

As discussed above, however, if a government enters tariff negotiations with domestic standards that discourage access to its markets relative to efficient standards policy (e.g., lax enforcement of environmental standards in its import-competing sector), then global efficiency will require this government to make future changes in its domestic policies which in themselves would increase access to its markets. In this event, the bindings necessary for this government to achieve an efficient level of implied market access would later impede its ability to deliver the promised access 
to its markets with an efficient mix of trade and domestic policies, as it would be prevented from adjusting its domestic policies in a way that increased access to its markets while offsetting these market access changes with a tariff increase above its bound level. This is captured by constraints (i) and (i*) in (IV) and (IV*), respectively, and when either of these constraints binds, the attainment of globally efficient outcomes is then impeded.

What is needed to remove this impediment, then, is a way to give governments the freedom to stabilize their implied market access commitments by raising their bound tariffs, when making changes to domestic policies that would otherwise increase access to their markets. Effectively, granting this additional freedom would amount to eliminating constraint (i) from the last stage of the two tariff negotiation games we have set out above, and this would eliminate (i) and (i*) from (IV) and $\left(\mathrm{IV}^{*}\right)$, respectively. As a result, this change would eliminate any impediments to achieving global efficiency that were associated with the features of existing standards. ${ }^{28}$

We summarize this observation with a final proposition:

Proposition 5: $\quad$ If governments were granted the freedom to stabilize their implied market access commitments by raising their bound tariffs, when making changes to domestic policies that would otherwise increase access to their markets, then: (i) any efficient combination of tariff bindings and standards policies could be implemented under tariff negotiations; and (ii) the politically optimal combination of policies could be implemented under reciprocal tariff negotiations.

Proposition 5 indicates that the primacy of market access concerns reflected in current GATT rules

\footnotetext{
${ }^{28} \mathrm{An}$ alternative would be to allow governments to record intended domestic policies at the start of tariff negotiations rather than existing domestic policies as our formal negotiation games assume. In fact, the failure to implement policy changes that were "promised" at the time of a round of tariff negotiations can be the basis for a nonviolation complaint under Article XXIII (see Petersmann, 1997, pp. 156-157). However, this solution would introduce an added strategic element to the choice of standards, which could add a new source of inefficiency (and which would be absent under the solution proposed above).
} 
can be harnessed to eliminate the remaining inefficiencies associated with standard-setting under these rules, if governments are given more sovereignty than these rules currently provide to choose the policy mix with which to deliver their market access commitments. ${ }^{29}$

Notice that the impediment to global efficiency that we have identified under current GATT rules bears a resemblance to race-to-the-bottom-type fears, under which trade pressures could delay the introduction or enforcement of stricter labor or environmental standards. Our analysis therefore identifies an element of truth in these fears, in that GATT rules may not provide governments with sufficient flexibility in all circumstances to offset the trade pressures that could otherwise impede the implementation of efficient domestic standards. This is the case, even when the flexibility to renegotiate market access commitments that GATT permits is modeled, as in Proposition 4. However, in light of the need for added flexibility, our analysis does point to the renegotiation provisions of GATT as a potentially fruitful area within which to introduce the modifications that could eliminate this impediment. ${ }^{30}$ In this light, our analysis can be viewed as validating GATT's continued emphasis on market access concerns, and as pointing to refinements of GATT's renegotiation provisions under which governments could better achieve globally efficient trade and domestic policies.

Also important, however, is a direction in which our analysis does not point, namely, the direction taken by proposals for the creation of a GATT "social clause." As we have observed above, direct negotiations over $\left(\tau, s_{q}, s_{c}, \tau^{*}, s_{q}{ }^{*}, s_{c}{ }^{*}\right)$ could of course allow governments to move to a point on the efficiency frontier. But this is not what the social clause envisions. Instead, under current proposals, a set of minimum international standards would first be negotiated, and subsequently each country would be allowed to deny market access to any trading partner that did not meet these standards. These proposals reflect an underlying belief that the race to the bottom is fueled by the

\footnotetext{
${ }^{29}$ We note also that, with this modification of GATT's rules, the restriction that tariffs and domestic standards are sufficiently close substitutes for meeting market access objectives is no longer needed to establish that the politically optimal combination of policies can be implemented under reciprocal tariff negotiations.

${ }^{30}$ For instance, the renegotiation provisions of Article XXVIII might be modified to facilitate the possibility of offering changes in domestic standards as a "compensatory adjustment" when raising the bound rate of a tariff.
} 
policy choices of low-standards countries and the trade pressures that these choices exert on the industrialized world. Under this logic, the race to the bottom can be stopped by making access to one's markets conditional on the standards choices of one's trading partners. But while we have identified an element of truth in the race-to-the-bottom fears under existing GATT rules, the engines of this race are fueled by the loss in trade competitiveness that would result from a tightening of one's own standards, not by greater import competition from a low-standards trading partner. Consequently, the inefficiency associated with the race to the bottom cannot as a general matter be eliminated by modifying GATT's rules to forge a direct link, of the form envisioned under the social clause, between one's market access commitments and the choice of standards made by one's trading partner. ${ }^{31}$ From this perspective, our analysis indicates that the logic of a GATT social clause is fundamentally flawed.

\section{Conclusion}

How should the issue of domestic standards be handled in the WTO? Our analysis suggests that GATT's principles are already well-equipped to address this issue, and that with some modification these principles could allow governments to attain globally efficient trade and domestic policies. The modification would provide governments with the freedom to increase their bound tariff rates when making changes to their domestic policies that would otherwise increase foreign access to their markets. As GATT principles already effectively require governments to grant compensatory tariff reductions when altering their domestic policies in ways that would erode foreign access to their markets, these modifications can be viewed as refinements of existing GATT rules that are consistent with GATT principles.

While in principle our results point toward a relatively simple "fix" for the contentious issue

\footnotetext{
${ }^{31}$ This can be seen formally by considering how the introduction of a social clause would augment (IV) and (IV*) and the tariff negotiating games we have set out above. Under a GATT social clause as currently proposed, countries would in the first stage negotiate as well a set of minimum international standards $\left(\bar{s}_{q}, \bar{s}_{c}\right)$, and then in the final stage a third constraint would be added of the form $\left(s_{q} \geq \bar{s}_{q} ; s_{c} \geq \bar{s}_{c}\right)$ to (IV), and of the form $\left(s_{q} \geq \bar{s}_{q} ; s_{c}{ }^{*} \geq \bar{s}_{c}\right)$ to (IV*). It is now a short step from the augmented (IV) and (IV*) to see that the introduction of a GATT social clause could not eliminate the inefficiencies that exist under current GATT rules except in the special case where efficiency required uniform standards across countries.
} 
of standards in the WTO, in practice there are of course a host of important caveats which must be borne in mind. First among these is the "slippery slope" argument that asks of the WTO, "Why stop at labor and environmental standards?" To some degree virtually all domestic policy choices of large economies such as the United States will have implications for export prices in the world economy and hence could be the subject of an analysis similar to that which we have undertaken here. Where, then, should the WTO draw the line? Also important is the question of how, given the complexities of the real world, the trade effects of a given change in domestic standards could be assessed with any accuracy. ${ }^{32}$ These and other arguments might well be offered up against the advisability of modifying the rules of GATT in the way that our formal results suggest.

On the other hand, the direct negotiation of a list of minimum international standards and the subsequent enforcement of a WTO "social clause" is itself an extraordinarily complex task, and not one which is immune to the "slippery slope" argument. At the same time, this approach crosses a boundary of national sovereignty that has served GATT well for 50 years. Moreover, as we have observed, there is a key difference between harnessing the logic of GATT's current principles to address the issue of labor and environmental standards and negotiating a social clause. Under the logic of GATT's current principles, there exists an implicit link, created by the prospect of nonviolation complaints, between a government's labor and environmental policies and its own market access commitments, and we have argued that this link should be strengthened. In contrast, under the logic of a GATT social clause, countries would face restricted access to the markets of their trading partners if they do not meet a set of minimum international standards, and so a direct link would be forged between a government's labor and environmental policies and the market access commitments of its trading partners. We find no support for the creation of such a linkage in our formal analysis. Consequently, our results indicate that, as a means of addressing legitimate problems associated with the choice of labor and environmental standards under existing GATT rules, the logic

\footnotetext{
${ }^{32}$ The general difficulty of assessing the trade effects of a given unilateral policy change arises as well in the context of Kemp-Wan adjustments (see also note 22), and in the context of customs union formation these difficulties have been discussed by McMillan (1993) and Srinivasan (1997). Nevertheless, it should be pointed out that these difficulties have not prevented GATT panels from proceeding in non-violation cases, where the trade effects of domestic policy changes are precisely what is at stake.
} 
of a GATT social clause is fundamentally flawed.

Finally, we mention a couple of interesting issues for future research. One issue concerns the potential gap between GATT principles as we have modeled them and GATT practice. It is possible that, while GATT principles can serve as we have indicated to deliver governments to the efficiency frontier, in practice governments may fall far short of this ideal. Hence, efforts to bring GATT practice more in line with GATT principles (by, for example, enhancing enforcement of GATT rules) may be an important element of handling the issue of domestic standards within the WTO, and this may therefore provide an interesting further line of research. A second observation, in light of our results here, concerns the handling of intellectual property rights protection within the WTO. One result of the Uruguay Round of GATT negotiations was a new agreement on Trade-Related Aspects of Intellectual Property Rights (TRIPs). Under the TRIPs agreement, WTO members have accepted obligations on minimum standards for the protection of intellectual property rights and their enforcement, much as the proposed social clause would introduce for labor standards. An interesting question is whether there are special features associated with the protection of intellectual property (e.g., non-pecuniary externalities) that would warrant such an approach in this case. We leave these and other topics for future research. 


\section{Appendix}

\section{Proof of Proposition 4:}

In the Three-Stage Tariff Negotiation Game, the first stage is significant only in its determination of the implied world price, $\bar{p}^{w}$. Given this world price, governments make secondstage proposals, $\hat{\tau}=\hat{\tau}\left(\bar{p}^{w} ;\right)$ and $\hat{\tau}^{*}=\hat{\tau}^{*}\left(\bar{p}^{w} ; \cdot\right)$, where the unspecified arguments reflect existing standards. Given that the iso-world-price locus is upward sloping in the $\tau-\tau^{*}$ plane, with trade volume decreasing monotonically along this locus as tariffs rise, the second-stage proposals determine the second-stage outcome as follows:

$$
\begin{array}{ll}
\left.\tilde{\tau}_{(\bar{p}} \bar{p}^{w} ;\right) \equiv \max \left(\hat{\tau}, \tau\left(\hat{\tau}^{*}, \bar{p}^{w} ;\right)\right) ; & \tilde{\tau}^{*}\left(\bar{p}^{w} ; \cdot\right) \equiv \max \left(\hat{\tau}^{*}, \tau^{*}\left(\hat{\tau}, \bar{p}^{w} ; \cdot\right)\right) ; \\
\tilde{M}_{x}\left(\bar{p}^{w} ; \cdot\right) \equiv M_{x}\left(s_{q}^{0}, s_{c}^{0}, p\left(\tilde{\tau}, \bar{p}^{w} ; \cdot\right), \bar{p}^{w}\right) ; & \tilde{M}_{y}^{*}\left(\bar{p}^{w} ; ;\right) \equiv M_{y}^{*}\left(s_{q}^{* 0}, s_{c}^{* 0}, p^{*}\left(\tilde{\tau}^{*}, \bar{p}^{w} ; \cdot\right), \bar{p}^{w}\right),
\end{array}
$$

where $\tilde{\tau}=\tilde{\tau}\left(\bar{p}^{w} ; \cdot\right)$ and $\tilde{\tau}^{*}=\tilde{\tau}^{*}\left(\bar{p}^{w} ; \cdot\right)$. We note that $\tilde{\tau}^{*}=\tau^{*}\left(\tilde{\tau}, \bar{p}^{w} ; ;\right)$ and $\bar{p}^{w}=\tilde{p}^{w}\left(\tilde{\tau}, s_{q}^{0}, s_{c}^{0}, \tilde{\tau}^{*}, s_{q}^{* 0}, s_{c}^{* 0}\right)$. Finally, in the third stage, the domestic government chooses $\left(\tau, s_{q}, s_{c}\right)$ to solve (IV), where $\bar{\tau}=\tilde{\tau}$ and $\bar{M}_{x}=\tilde{M}_{x}\left(\bar{p}^{w} ; \cdot\right)$; and similarly the foreign government chooses $\left(\tau^{*}, s_{q}{ }^{*}, s_{c}{ }^{*}\right)$ to solve $(\mathrm{IV} *)$ where $\bar{\tau}^{*}=\tilde{\tau}^{*}$ and $\bar{M}_{y}^{*}=\tilde{M}_{y}^{*}\left(\bar{p}^{w} ;\right)$.

Consider now an efficient combination of tariff bindings and standards policies, $\left(\tau^{E}, s_{q}^{E}, s_{c}{ }^{E}, \tau^{* E}, s_{q}^{* E}, s_{c}^{* E}\right)$. Note that, if this policy combination solves (IV) and (IV*), then at this combination constraints (ii) and (ii*) must hold with strict equality, with the associated multipliers strictly positive, and therefore $\bar{p}^{w}, \tilde{M}_{x}\left(\bar{p}^{w} ;\right)$ and $\tilde{M}_{y}^{*}\left(\bar{p}^{w} ;\right)$ must satisfy

$$
M_{x}\left(s_{q}^{E}, s_{c}^{E}, p\left(\tau^{E}, \bar{p}^{w}\right), \bar{p}^{w}\right)=\tilde{M}_{x}\left(\bar{p}^{w} ; \cdot\right) ; \quad M_{y}^{*}\left(s_{q}^{* E}, s_{c}^{* E}, p^{*}\left(\tau^{* E}, \bar{p}^{w}\right), \bar{p}^{w}\right)=\tilde{M}_{y}^{*}\left(\bar{p}^{w} ; \cdot\right)
$$

For suppose this were not the case, and suppose in particular that at this efficient policy combination the home country's constraint (ii) held with strict inequality. Then with $\tau$ set at $\tau^{E}$, it would be feasible for the home country to alter $s_{q}$ and $s_{c}$ from their efficient levels so as to reduce domesticmarket access and still satisfy (ii), and home welfare could be strictly improved in this fashion by Proposition 2 (see also note 25), and so this policy combination could not solve (IV). Observe also 
that if (ii) and (ii*) hold with equality, it follows from (1) and (2) that $\bar{p}^{w}=\tilde{p}^{w E}$, where $\tilde{p}^{w E}$ denotes the equilibrium world price associated with the particular efficient policy combination under consideration. Hence, defining $\tilde{\tau}^{E}$ by $M_{x}\left(s_{q}^{0}, s_{c}^{0}, p\left(\tilde{\tau}^{E}, \tilde{p}^{w E} ; \cdot\right), \tilde{p}^{w E}\right)=M_{x}^{E}$ and defining $\tilde{\tau}^{* E}$ by $M_{y}^{*}\left(s_{q}^{* 0}, s_{c}^{* 0}, p^{*}\left(\tilde{\tau}^{* E}, \tilde{p}^{w E} ;\right), \tilde{p}^{w E}\right)=M_{y}^{* E}$ where $M_{x}^{E}$ and $M_{y}^{* E}$ denote the trade volumes corresponding to the efficient policy combination $\left(\tau^{E}, s_{q}^{E}, s_{c}^{E}, \tau^{* E}, s_{q}{ }^{* E}, s_{c}{ }^{* E}\right)$, a necessary condition for this policy combination to be implemented under reciprocal tariff negotiations is that

(A1). $\quad \bar{p}^{w}=\tilde{p}^{w E} ; \tilde{\tau}\left(\tilde{p}^{w E}: \cdot\right)=\tilde{\tau}^{E} ;$ and $\tilde{\tau}^{*}\left(\tilde{p}^{w E} ; \cdot\right)=\tilde{\tau}^{* E}$.

We now prove in sequence the three results contained in Proposition 4: I) If an efficient policy combination is not politically optimal, then it cannot be implemented under reciprocal tariff negotiations; II) If an efficient policy combination is politically optimal but the existing standards of either government discourage market access relative to the efficient politically optimal standards policies, then this policy combination cannot be implemented under reciprocal tariff negotiations; and III) If an efficient policy combination is politically optimal and the existing standards of each government encourage market access relative to the efficient politically optimal standards policies, then this policy combination can be implemented under reciprocal tariff negotiations

I) Consider any policy combination $\left(\tau^{E}, s_{q}{ }^{E}, s_{c}{ }^{E}, \tau^{* E}, s_{q}{ }^{* E}, s_{c}{ }^{* E}\right)$ that is efficient but that is not the politically optimal combination, and suppose that this combination can be implemented under reciprocal tariff negotiations. Then, given the existing standards, there exists $\bar{p}^{w}$ such that the stage 2-3 subgame yields this efficient combination outcome as a subgame perfect Nash equilibrium. Moreover, by (A1) we must have $\bar{p}^{w}=\tilde{p}^{w E}$, with the outcome of Stage 2 characterized by $\tilde{\tau}\left(\tilde{p}^{w E}: \cdot\right)=\tilde{\tau}^{E}$ and $\tilde{\tau}^{*}\left(\tilde{p}^{w E} ;{ }^{\prime}\right)=\tilde{\tau}^{* E}$, so that in Stage 3 and at the efficient choices, constraints (ii) and (ii*) hold with strict equality and the associated multipliers are strictly positive.

From (10), it may now be derived that an efficient policy mix satisfies $\operatorname{sign}\left\{W_{p}\right\}=\operatorname{sign}\left\{W_{p^{*}}^{*}\right\}$. Thus, if $W_{p}=0$, then $W_{p^{*}}^{*}=0$, and (8) and (9) imply further that $W_{s_{q}}=0=W_{s_{c}}$ and $W_{s_{q}^{*}}^{*}=0=W_{s_{c}^{*}}^{*}$. Given our supposition that the efficient combination is not the politically optimal combination, it must be 
that at $\left(\tau^{E}, s_{q}{ }^{E}, s_{c}{ }^{E}, \tau^{* E}, s_{q}{ }^{* E}, s_{c}{ }^{* E}\right)$ we have either $W_{p}>0$ and $W_{p^{*}}^{*}>0$ or $W_{p}<0$ and $W_{p^{*}}^{*}<0$. For simplicity, we take the former case, wherein the domestic (foreign) government prefers a higher local price and thus less (more) trade, given $\tilde{p}^{w E}$.

In this case, given that the multipliers associated with constraints (ii) and (ii*) in (IV) and $\left(\mathrm{IV}^{*}\right)$ are strictly positive at the efficient policy combination, if the foreign government makes a Stage-2 proposal consistent with $\tilde{\tau}^{*}\left(\tilde{p}^{w E} ; \cdot\right)=\tilde{\tau}^{* E}$, then the home government can profit by deviating from a Stage-2 proposal consistent with $\tilde{\tau}\left(\tilde{p}^{w E}: \cdot\right)=\tilde{\tau}^{E}$ to the proposal $\hat{\tau}=\tilde{\tau}^{E}+\epsilon$. To see this, note first that the home-government's deviant proposal will be pivotal, and so if the resulting world price is not altered from $\tilde{p}^{w E}$ under this deviation, then the home government achieves less trade volume at a fixed world price and hence, with $W_{p}>0$, it will gain from such a deviation. And in fact, given that the multipliers associated with (ii) and (ii*) are strictly positive at the efficient policy combination, a sufficiently small deviation (small $\epsilon$ ) will imply a sufficiently small drop in $\tilde{M}_{x}\left(\tilde{p}^{w E}\right)$ below $M_{x}^{E}$ and in $\tilde{M}_{y}^{*}\left(\tilde{p}^{w E}\right)$ below $M_{y}^{* E}$ so that (ii) and (ii*) must continue to hold with equality in Stage 3 , and thus the resulting world price will indeed not be altered from $\tilde{p}^{w E}$. Hence, with a profitable deviation now described, we may conclude that, if an efficient policy combination is not politically optimal, it cannot be implemented under reciprocal tariff negotiations.

II) Suppose next that the efficient combination is the politically optimal combination $\left(\tau^{p o}, s_{q}^{p o}, s_{c}^{p o}, \tau^{* p o}, s_{q}^{* p o}, s_{c}^{* p o}\right)$, and that the existing standards are set by at least one government in a way that discourages access to its markets relative to the efficient politically optimal standards policies. Suppose that it is the existing standards of the domestic government that discourage market access relative to efficient politically optimal levels. Suppose further that such a policy combination can be implemented under reciprocal tariff negotiations. Define $M_{x}^{p o}, M_{y}^{* p o}$ and $\tilde{p}^{w p o}$ as the associated politically optimal trade volumes and world price. Then $\tilde{\tau}^{p o}$ and $\tilde{\tau}^{* p o}$ are defined, respectively, by $M_{x}\left(s_{q}^{0}, s_{c}^{0}, p\left(\tilde{\tau}^{p o}, \tilde{p}^{w p o} ; \cdot\right), \tilde{p}^{w p o}\right)=M_{x}^{p o}$ and $M_{y}^{*}\left(s_{q}^{* 0}, s_{c}^{* 0}, p^{*}\left(\tilde{\tau}^{* p o}, \tilde{p}^{w p o} ; \cdot\right), \tilde{p}^{w p o}\right)=M_{y}^{* p o}$, and observe that $\tau^{p o}>\tilde{\tau}^{p o}$. Clearly, by constraint (i) in (IV) we must also have $\tilde{\tau}\left(\tilde{p}^{w p o} ;\right) \geq \tau^{p o}$. But then $\tilde{\tau}\left(\tilde{p}^{w p o} ;\right)>\tilde{\tau}^{p o}$, and hence by (A1) this policy combination cannot be implemented under reciprocal tariff negotiations. 
III) Suppose finally that the efficient combination is the politically optimal combination $\left(\tau^{p o}, s_{q}^{p o}, s_{c}^{p o}, \tau^{* p o}, s_{q}^{* p o}, s_{c}^{* p o}\right)$, and that the existing standards are set by each government in a way that encourages access to its markets relative to the efficient politically optimal standards policies. Then $\tau^{p o} \leq \tilde{\tau}^{p o}$ and $\tau^{* p o} \leq \tilde{\tau}^{* p o}$. Suppose now that Stage-1 negotiations imply the politically optimal world price $\left(\bar{p}^{w}=\tilde{p}^{w p o}\right)$, and that the home and foreign governments make politically optimal proposals in Stage 2 given by $\hat{\tau}=\tilde{\tau}^{p o}$ and $\hat{\tau}^{*}=\tilde{\tau}^{* p o}$, respectively. Then the necessary condition (A1) for implementing the politically optimal policy combination under reciprocal tariff negotiations is satisfied: $\bar{p}^{w}=\tilde{p}^{w p o} ; \tilde{\tau}\left(\tilde{p}^{w p o}: \cdot\right)=\tilde{\tau}^{p o} ;$ and $\tilde{\tau}^{*}\left(\tilde{p}^{w p o} ; \cdot\right)=\tilde{\tau}^{* p o}$. Note as well that $\tilde{M}_{x}\left(\tilde{p}^{w p o} ; \cdot\right)=M_{x}^{p o}$ and $\tilde{M}_{y}^{*}\left(\tilde{p}^{w p o} ;\right)=M_{y}^{* p o}$. It now follows from (IV) with $\bar{\tau}=\tilde{\tau}^{p o}$ and $\bar{M}_{x}=M_{x}^{p o}$ and from (IV*) with $\bar{\tau}^{*}=\tilde{\tau}^{* p o}$ and $\bar{M}_{y}^{*}=M_{y}^{* p o}$ that the politically optimal policy combination $\left(\tau^{p o}, s_{q}^{p o}, s_{c}^{p o}, \tau^{* p o}, s_{q}^{* p o}, s_{c}{ }^{* p o}\right)$ constitutes a Nash equilibrium to the Stage-3 subgame. To see this, note that if, say, the foreign government selects $\left(\tau^{* p o}, s_{q}^{* p o}, s_{c}^{* p o}\right)$, then it meets its market access constraint (ii*) with equality, and thus the home government selects its policies to solve (IV'). But with (ii') preventing an improvement in the home country's terms of trade beyond $\tilde{p}^{w p o}$, the best the home government can do is to achieve its ideal position along this iso-world-price locus, and hence its politically optimal level of welfare, by responding with $\left(\tau^{p o}, s_{q}^{p o}, s_{c}^{p o}\right)$, which is also feasible.

What remains in order to establish that the political optimum may indeed be implemented under reciprocal tariff negotiations in this case is to show that the home proposal $\hat{\tau}=\tilde{\tau}^{p o}$ is a bestresponse to the foreign proposal $\hat{\tau}^{*}=\tilde{\tau}^{* p o}$ (and vice versa) in Stage 2. We consider the home proposal, and note that analogous arguments apply for the foreign government. We begin by observing that, to improve upon its politically optimal payoff, the home government must secure a favorable movement in its terms of trade, and hence by (IV') it must induce a Nash equilibrium of the Stage-3 subgame in which the foreign government makes policy selections in Stage 3 which satisfy the foreign market access constraint (ii*) with strict inequality. Hence, the possible gain to the home government in deviating from the politically optimal Stage-2 proposal $\hat{\tau}=\tilde{\tau}^{p o}$ comes from placing the foreign government in a position in Stage 3 where its implied market access commitment is below that consistent with its best-response policies, and therefore it must be that (6) - which defines the foreign best-response standards - is satisfied in the Nash equilibrium of Stage 3. There are then two cases 
to consider, corresponding to whether or not the foreign constraint ( $\left.i^{*}\right)$ binds in the Nash equilibrium of the Stage-3 subgame.

If $\left(i^{*}\right)$ holds with strict inequality, then the foreign government is setting its best-response tariff in Stage 3 so that, in addition to (6), (7) also holds. As the domestic constraints (i) and (ii) are inequality constraints, the home government cannot be held above its best-response policies in Stage 3 , but may be held below them by its Stage- 2 proposal. Consequently, in this case, with its Stage- 2 deviation the home government may engineer a move from the political optimum to a point that rests on the foreign government's reaction curves and below its own reaction curves (i.e., a tariff below its best-response tariff and/or market-access provision above that consistent with its best-response policies). But this can yield the home government no greater welfare than it could achieve in the Two-Stage Non-cooperative Policy Game were it able to select in Stage 1 of this game any point on the foreign Stage-1 reaction function that left the home government below its Stage-1 reaction function, which we have assumed is in turn no better than the home government's politically optimal payoff. Hence, deviating from the political optimum in this case cannot be profitable.

Finally, suppose that (i*) holds with strict equality in the Nash equilibrium of the Stage 3 subgame. In this case, the foreign government is held below its best-response tariff by the tariff binding implied by the home government's deviant proposal, though as (ii*) is satisfied with strict inequality the foreign government is still unconstrained in the Nash equilibrium of the Stage-3 subgame by its Stage- 2 market access commitment. The potential additional benefit afforded to the home government from the ability to bind the foreign tariff may be understood to derive from the impact of this binding on the foreign government's market-access determination in Stage 3. However, a foreign tariff binding will be ineffective in significantly influencing this determination if tariffs and standards policies are sufficiently close substitutes for meeting the market access objectives. Consequently, with sufficient substitutability as we have assumed, the additional possibility of binding the foreign government's tariff that comes with this second case cannot make a deviation from the political optimum profitable. 


\section{References}

Bagwell, Kyle and Robert W. Staiger, "Reciprocal Trade Liberalization," NBER Working Paper No. 5488, March 1996.

Bagwell, Kyle and Robert W. Staiger, "The Simple Economics of Labor Standards and the GATT," NBER Working Paper No. 6604, June 1998.

Bagwell, Kyle and Robert W. Staiger, "An Economic Theory of GATT," American Economic Review 89, March 1999a, pp. 215-248.

Bagwell, Kyle and Robert W. Staiger, "Multilateral Trade Negotiations, Bilateral Opportunism and the Rules of GATT," NBER Working Paper No. 7071, April $1999 \mathrm{~b}$.

Bhagwati, Jagdish and Robert E. Hudec (eds.), Fair Trade and Harmonization: Prerequisites for Free Trade?, Volume 2 (Legal Analysis), The MIT Press, Cambridge, 1996.

Bhagwati, Jagdish and TN Srinivasan, "The Theory of Wage Differentials: Production Response and Factor Price Equalisation,” Journal of International Economics1 (1971), pp. 19-35.

Brecher, Richard A., "Optimal Commercial Policy for a Minimum-Wage Economy," Journal of International Economics 4 (1974), pp. 139-149.

Brown, Drusilla K., Deardorff, Alan V. and Robert M. Stern, "International Labor Standards and Trade: A Theoretical Analysis," in Bhagwati and Hudec (eds.), Fair Trade and Harmonization: Prerequisites for Free Trade?, Volume 1 (Economic Analysis), The MIT Press, Cambridge, 1996.

Copeland, Brian, "Strategic Interaction among Nations: Negotiable and Non-negotiable Trade Barriers," Canadian Journal of Economics 23 (1990), pp. 64-108.

Dam, Kenneth W., The GATT: Law and International Economic Organization, Chicago: University of Chicago Press, 1970.

Ederington, Josh, “International Coordination of Trade and Domestic Policies," mimeo, May 1999.

Enders, Alice, "The Role of the WTO in Minimum Standards," in van Dijck and Faber (eds.), Challenges to the New World Trade Organization, Kluwer Law International, The Hague, 1996.

Flam, Harry and Elhanan Helpman, "Industrial Policy under Monopolistic Competition," Journal of International Economics 22 (1987), pp. 79-102.

Jackson, John H., World Trade and the Law of GATT, Bobbs-Merrill, New York, 1969.

Jackson, John H., The World Trading System. (The MIT Press, Cambridge: 1989).

Kemp, Murray C. and Henry Wan, Jr., “An Elementary Proposition Concerning the Formation of Customs Unions,” Journal of International Economics 6, 1976, pp. 95-98. 
McMillan, John, "Does Regional Integration Foster Open Trade? Economic Theory and GATT's Article XXIV," in Anderson and Blackhurst (eds.), Regional Integration and the Global Trading System, St. Martin's Press, New York, 1993.

Petersmann, Ernst-Ulrich, The GATT/WTO Dispute Settlement System: International Law, International Organizations and Dispute Settlement, Kluwer Law International, The Hague, 1997.

Robinson, J., "Beggar-My-Neighbor Remedies for Unemployment," Chapter 2 of Essays on the Theory of Unemployment, $2^{\text {nd }}$ Edition: Basil Blackwell, Oxford, 1947.

Roessler, Frieder, "Domestic Policy Objectives and the Multilateral Trade Order: Lessons from the Past," in Anne O. Krueger (ed.), The WTO as an International Organization, The University of Chicago Press, Chicago and London, 1998.

Spagnolo, Giancarlo, "Issue Linkage, Delegation, and International Policy Cooperation,” mimeo, March 1999.

Srinivasan, T.N., "International Trade and Labour Standards from an International Perspective," in van Dijck and Faber (eds.), Challenges to the New World Trade Organization, Kluwer Law International, The Hague, 1996.

Srinivasan, T.N., "The Common External Tariff of a Customs Union: Alternative Approaches," Japan and the World Economy 9, 1997, pp. 447-465.

Winters, L. Alan, "Regionalism and the Rest of the World: The Irrelevance of the Kemp-Wan Theorem," Oxford Economic Papers, April 1997, pp. 228-34.

WTO, "Report of the Panel: European Communities-Regime for the Importation, Sale and Distribution of Bananas-Recourse to Article 21.5 by the European Communities," Report WT/DS27/RW/EEC, April 12, 1999. 


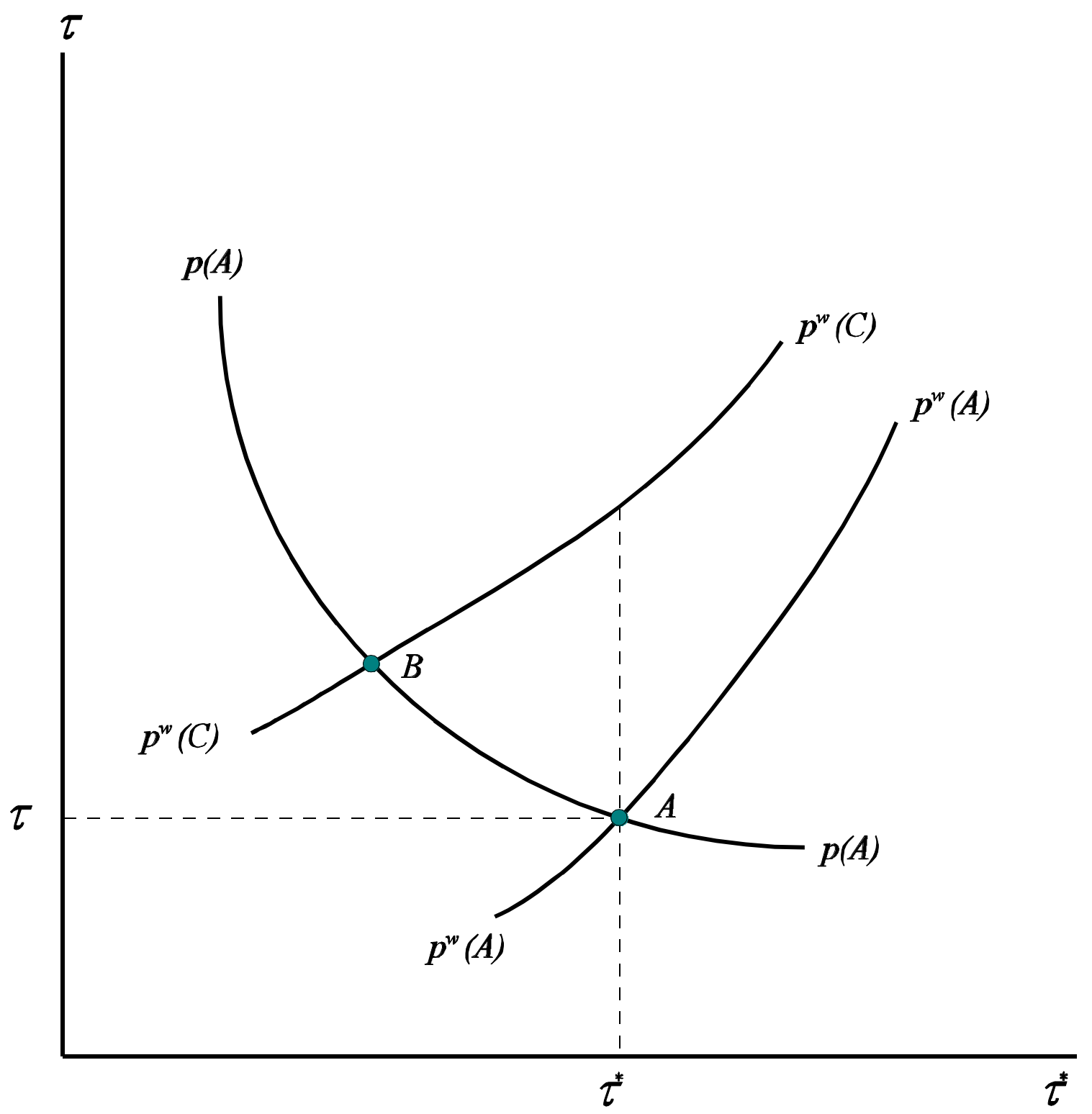

Figure 1

Figure 1: The world- and local-price effects of a tariff change. 